\title{
Assessing Stream-Aquifer Connectivity in a Coastal California Watershed
}

\author{
Bwalya Malama ${ }^{1, * \mathbb{D}}$, Devin Pritchard-Peterson ${ }^{1,+}$, John J. Jasbinsek ${ }^{2} \mathbb{D}$ and Christopher Surfleet ${ }^{1} \mathbb{D}$ \\ 1 Department of Natural Resources Management \& Environmental Sciences, California Polytechnic State \\ University, San Luis Obispo, CA 93407, USA; devin.spp@gmail.com (D.P.-P.); csurflee@calpoly.edu (C.S.) \\ 2 Physics Department, California Polytechnic State University, San Luis Obispo, CA 93407, USA; \\ jjasbins@calpoly.edu \\ * Correspondence: bmalama@calpoly.edu; Tel.: +1-805-756-2971 \\ + Current address: DUDEK, San Diego, CA 93407, USA.
}

Citation: Malama, B.; Pritchard-

Peterson, D.; Jasbinsek, J.J.; Surfleet,

C. Assessing Stream-Aquifer

Connectivity in a Coastal California Watershed. Water 2021, 13, 416.

https://doi.org/10.3390/w13040416

Academic Editor: Aldo Fiori

Received: 28 December 2020

Accepted: 29 January 2021

Published: 5 February 2021

Publisher's Note: MDPI stays neutral with regard to jurisdictional clai$\mathrm{ms}$ in published maps and institutional affiliations.

Copyright: (C) 2021 by the authors. Licensee MDPI, Basel, Switzerland. This article is an open access article distributed under the terms and conditions of the Creative Commons Attribution (CC BY) license (https:// creativecommons.org/licenses/by/ $4.0 /)$.
Abstract: We report the results of field and laboratory investigations of stream-aquifer interactions in a watershed along the California coast to assess the impact of groundwater pumping for irrigation on stream flows. The methods used include subsurface sediment sampling using direct-push drilling, laboratory permeability and particle size analyses of sediment, piezometer installation and instrumentation, stream discharge and stage monitoring, pumping tests for aquifer characterization, resistivity surveys, and long-term passive monitoring of stream stage and groundwater levels. Spectral analysis of long-term water level data was used to assess correlation between stream and groundwater level time series data. The investigations revealed the presence of a thin low permeability silt-clay aquitard unit between the main aquifer and the stream. This suggested a three layer conceptual model of the subsurface comprising unconfined and confined aquifers separated by an aquitard layer. This was broadly confirmed by resistivity surveys and pumping tests, the latter of which indicated the occurrence of leakage across the aquitard. The aquitard was determined to be 2-3 orders of magnitude less permeable than the aquifer, which is indicative of weak stream-aquifer connectivity and was confirmed by spectral analysis of stream-aquifer water level time series. The results illustrate the importance of site-specific investigations and suggest that even in systems where the stream is not in direct hydraulic contact with the producing aquifer, long-term stream depletion can occur due to leakage across low permeability units. This has implications for management of stream flows, groundwater abstraction, and water resources management during prolonged periods of drought.

Keywords: stream depletion; aquifer; aquitard; leakage; hydraulic conductivity; resistivity; connectivity; spectral analysis

\section{Introduction}

That groundwater is inextricably linked to surface flows and that groundwater abstraction can lead to stream depletion are well established (see [1] and the references therein). Stream depletion can lead to such adverse effects as diminished surface water supplies for agricultural and municipal uses, riparian corridor degradation, and aquatic ecosystem destruction [2]. In 2014, the state of California passed the Sustainable Groundwater Management Act, which lists depletion of surface flows among the six undesirable results of unsustainable management of groundwater resources. A recent study by [3] demonstrated that an increase in groundwater abstraction across the U.S. over the last 100 years [4] has led to discernible impacts on the hydrologic cycle by decreasing stream flows and evapotranspiration at the watershed scale. In coastal California streams with rare, threatened, and/or endangered anadromous salmonids, decreases in instream flows during dry seasons are of particular concern. Groundwater inputs are particularly critical 
to maintaining instream flows through the dry season because coastal California experiences low summer rainfall and significant inter-annual variability in precipitation $[5,6]$. It is therefore important to understand the nature of stream-aquifer connectivity to help quantify depletion rates associated with groundwater pumping.

Over the past 70 years, extensive scientific research has improved the understanding of the factors and processes that control stream depletion due to groundwater pumping (see [1] and the references therein). Several workers have investigated the spatial and temporal response of instream flows to groundwater pumping in coastal California watersheds. For example, McGlochlin [7] examined the degree of stream-aquifer interaction in the lower Carmel Valley in Monterey County, California, and discovered, through groundwater monitoring and stream discharge measurements, that the aquifer and surface flows in the Carmel River are intimately connected, contrary to the prior understanding that a confining layer separates the two. Similarly, Kondolf et al. [8] used streamflow measurements and groundwater level data in wells to describe how groundwater withdrawals locally decreased baseflows and inhibited steelhead trout migration in the Carmel River. Fleckenstein et al. [9] evaluated groundwater management strategies to restore fall streamflows critical for supporting Chinook salmon runs in the Cosumnes River in Sacramento County, California. Their numerical modeling results suggested that extensive groundwater pumping reductions could improve long-term river conditions by reconnecting the river with the regional aquifer [9]. Studies such as those summarized above have led to increased knowledge of stream-aquifer exchange processes in coastal California watersheds. However, additional site-specific studies in these environments are still needed because the subsurface in such fluvial settings is inherently heterogeneous, with hydraulic properties that vary randomly in space and over many orders of magnitude [10]. Understanding such complex systems and developing sustainable groundwater pumping practices require detailed and site-specific investigation at the catchment or stream-reach scale, using a variety of tools and measurement techniques that integrate many spatial and temporal scales [11].

Typically, to determine stream depletion due to groundwater pumping, one conducts a pumping test, with aquifer drawdown monitored in observation wells. Such tests can range in duration from a few hours to $24 \mathrm{~h}$. Several analytical methods are available in the literature for determining stream depletion. They include those based on the solution of [12] for the confined aquifer flow problem. Theis [13] was one of the first to quantify stream depletion using a mathematical model for a confined aquifer fully penetrated by a stream. The solution was a simple modification, using the method of images, of the earlier solution [12] describing flow to a pumping well in an unbounded confined aquifer. Reference Theis [13] defined stream depletion as the decrease in stream discharge attributable to pumping. Glover and Balmer [14] showed that the solution of Theis [13] in closed-form is simply the complementary error function, which was later tabulated by Jenkins [15], who also introduced the concept of a stream depletion factor, defined as the time, from the onset of pumping, at which stream depletion is about $28 \%$ the pumping rate. The main limitation of these works is that the streambed is in direct hydraulic contact with the aquifer. Streambed hydraulic properties are, thus, the same as those of the aquifer. In all models based on the solution of [12], the stream is assumed to be fully penetrating, which means that it cuts across the entire thickness of the aquifer. The models cannot be used to analyze stream depletion in a multi layered system where a low permeability (aquitard) unit is sandwiched between the confined aquifer and the streambed. These models assume a stream that fully penetrates the pumped confined aquifer and cannot be used to analyze stream depletion in multi layered systems.

Other workers [16-23] have attempted to address these limitations. Additionally, for multi layered systems, it is difficult in practice to detect the effects of pumping on stream-aquifer exchanges during a typical single aquifer hydraulic test. Hantush [17] sought to simulate the effects of a low permeability unit between the stream and the aquifer using a semi-pervious streambed with a hydraulic conductivity that differs from 
that of the aquifer. According to Zlotnik et al. [19], Grigoryev [16] and Bochever [18] were the first to consider a partially penetrating stream under steady state (Thiem-type) flow conditions in an infinite domain. Zlotnik et al. [19] and Butler et al. [21] extended this to transient flow in infinite and finite domains, respectively. Hunt [20] developed a solution similar to that of Zlotnik et al. [19] for the limiting case of an infinitely thin streambed. Butler Jr et al. [24] considered stream depletion associated with pumping in a leaky confined aquifer partially penetrated by a stream and underlain by an aquitard of finite thickness. Hunt [22] considered stream depletion associated with groundwater abstraction from an unconfined aquifer using the theory of Boulton [25] for delayed-yield due to horizontal flow to a pumping well, with no flow across the base of the aquifer. Hunt [23] extended this work to a leaky unconfined aquifer system, using the classical leakage approach to describe aquitard flow. Additionally, for multi layered systems, it is difficult in practice to detect the effects of stream-aquifer exchanges during a typical pumping test. Drawdown response in observation wells does not attain a steady state as predicted by the models, at least for the pumping duration typically used in such tests. Numerical modeling and long-term hydraulic process monitoring at the field scale as performed recently by $[26,27]$ in Italy hold significant promise for quantifying and assessing stream-aquifer interactions.

In this study, we assess stream-aquifer connectivity using a detailed investigation of the subsurface and long-term passive groundwater level monitoring in a multi layered aquifer-aquitard system. First, we describe the field and laboratory methods used to characterize the subsurface. Next, we address the limitations of a single pumping test for stream depletion characterization using passively monitored long-term time series data of aquifer-aquitard-stream response to pumping and other system forcing. Spectral analysis of these time series is used to assess the degree of connectivity between the stream and the principal confined aquifer used as a source of irrigation water in the overlying agricultural fields. We aim to evaluate the impact of groundwater pumping for irrigation on stream flows, taking into account local site-specific subsurface hydrogeologic conditions. The results of the work underscore the utility and importance of long-term monitoring of such complex systems to better inform water resources managers. These results, investigation methods, and assessment tools may be extended and applied to similar multi layered subsurface systems with hydraulic connection to surface flows.

\section{Materials and Methods}

\subsection{Site Description}

Scotts Creek is a 7800 ha coastal watershed located approximately $100 \mathrm{~km}$ south of San Francisco in Santa Cruz County, California. It originates in the Santa Cruz Mountains within the Coast Range and meanders southwest for $19 \mathrm{~km}$ before emptying into the Pacific Ocean. The creek is fed by three perennial tributaries (Mill, Big, and Little creeks), three intermittent tributaries (Winter, Archibald, and Queseria creeks), and several small ephemeral drainages (Figure 1). An estuary at the outlet of the Scotts Creek watershed becomes a freshwater lagoon during the summer low flow period when a sandbar builds up at the creek mouth $[28,29]$. The climate of the region is Mediterranean, with warm, mostly dry summers and cool, wet winters. According to meteorological data collected by the California Irrigation Management Information System (CIMIS) automated weather station, located in Santa Cruz, California, about $21 \mathrm{~km}$ south from the study area, the mean summer air temperature highs are $24^{\circ} \mathrm{C}$ and mean winter air temperature lows are $5^{\circ} \mathrm{C}$. Based on precipitation data collected using an on-site rain gauge, the rainy season is typically from October through April, with an average yearly precipitation of $1270 \mathrm{~mm}$ and an average of $190 \mathrm{~mm}$ occurring in January. Even during the recent prolonged drought in California from December 2011 to March 2019, the average yearly precipitation was $900 \mathrm{~mm}$ (based on data from September 2011 through August 2018).

Scotts Creek supports the southernmost extant population of endangered coho salmon (Oncorhynchus kisutch) in North America and other sensitive species, including the steelhead 
trout (Oncorhynchus mykiss), tidewater goby (Eucyclogobius newberryi), and red-legged frog (Rana aurora) [28,29]. The lower portion of the watershed, where the study site is located, has a low surface elevation gradient and supports a thick riparian plant community of phreatophytes including red alder (Alnus rubra), arroyo willow (Salix lasiolepis), yellow willow (Salix lutea), and big leaf maple (Acer macrophyllum).

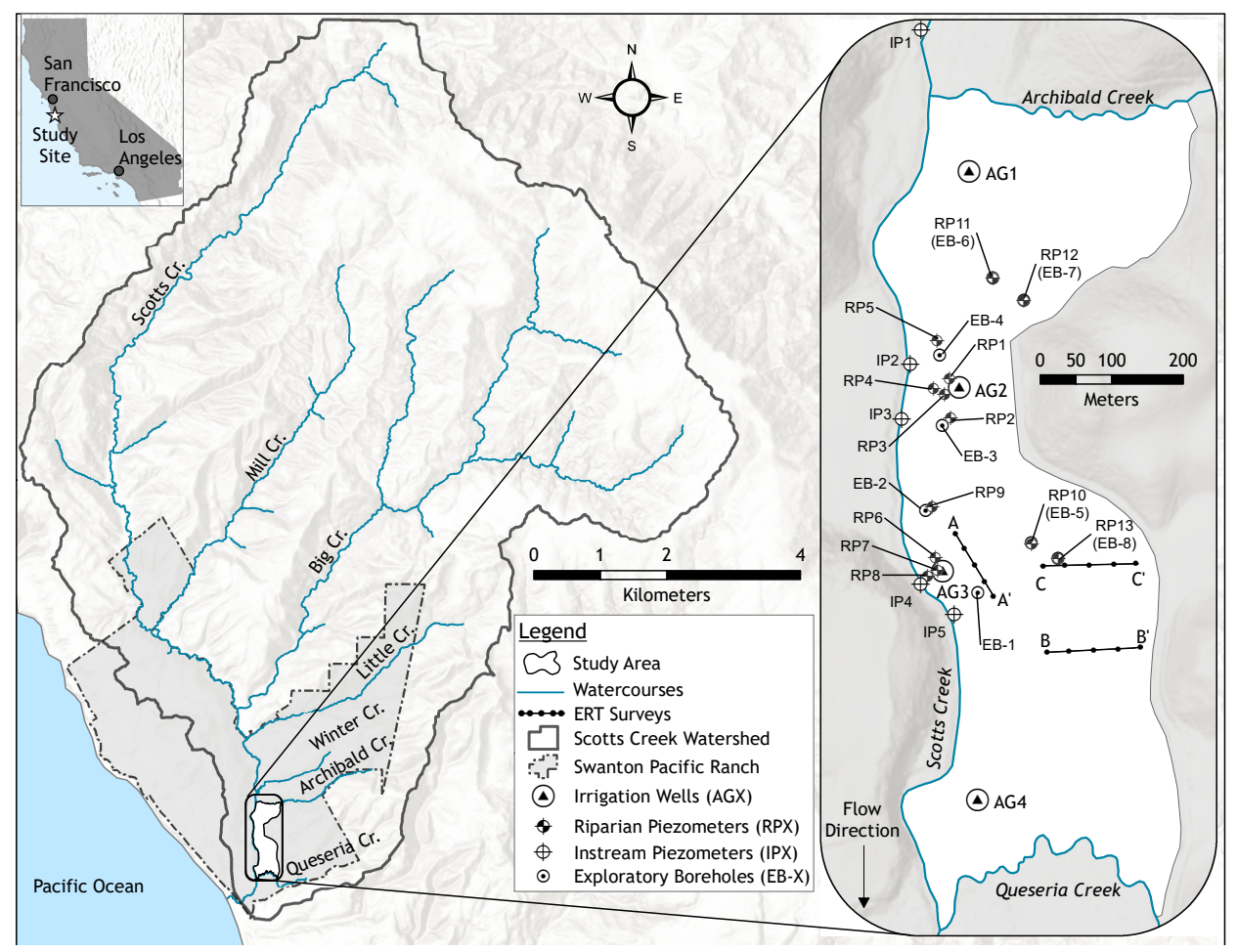

Figure 1. Map of the Scotts Creek (Cr.) watershed (center) and the study site (right) on the California central coast (top left). The locations of agricultural wells (AGX), instream (IPX), exploratory boreholes (EB-X), and riparian (RPX) piezometers, electrical resistivity surveys (ERT), and the study site bounding streams are marked.

\subsection{Geology and Hydrogeology}

The Scotts Creek watershed lies in the tectonically active central California Coast Ranges between the San Gregorio and San Andreas fault zones. The watershed rests on the Salinian block, which is comprised of dominantly quartz diorite (Cretaceous), Santa Margarita Sandstone (Miocene), and Santa Cruz Mudstone (Late Miocene). The sedimentary rocks (Santa Margarita Sandstone and Santa Cruz Mudstone) dominate the surface geology of the Scotts Creek watershed, but the granitic basement is evident in the upper reaches of the main stem and tributaries. The lower portion of the watershed consists of unconsolidated alluvium from mixed rock sources overlying Santa Cruz Mudstone bedrock.

In the study area, the surficial alluvium is the water bearing formation and has an average thickness of $33 \mathrm{~m}$. To determine aquifer thickness, well completion reports were obtained from the California Department of Water Resources (CDWR) for three of the four agricultural wells. The reports contain rudimentary lithologic descriptions that indicate a subsurface comprising a mixture of sand and gravel overlying green/brown shale. The shale bedrock was encountered at all drilling locations at an average depth of $33 \mathrm{~m}$. Table 1 shows the well completion reports used to discern aquifer thickness and depth to the base of the aquifer. There are two active irrigation wells, namely AG2 and AG3 (Figure 1), in the study area, both completed in the water bearing alluvium and situated within $50 \mathrm{~m}$ of the stream. The other wells are no longer in service. Based on records from the farm managers, the two actives wells are each pumped at an average rate of 200 gallons per minute (gpm; $1.26 \times 10^{-2} \mathrm{~m}^{3} / \mathrm{s}$ ) for up to $10 \mathrm{~h} /$ day on six days of the week, from the 
beginning of May to the end of October to supply irrigation water for about 25 ha of prime agricultural cropland in lower Scotts Creek. The greatest groundwater withdrawals occur from July to September when crop water demands are highest. This period of the highest groundwater withdrawals coincides with the dry period of the year during which instream flows are sustained by baseflow and are receding, reaching critically low levels averaging $0.1 \mathrm{~m}^{3} / \mathrm{s}$, as measured on a stream gauge upstream of well AG2, before drying up until the the first rain events in the fall. In the winter, the creek exhibits peak flows ranging from 20 to $70 \mathrm{~m}^{3} / \mathrm{s}$.

\subsection{Field and Laboratory Measurements}

To understand the connectivity of the stream to the underlying aquifer, we first characterized the aquifer using direct-push subsurface sampling, laboratory analysis of subsurface samples, geophysical resistivity surveys, and pumping tests. The subsurface piezometers were then instrumented with pressure transducers for passive long-term monitoring of groundwater level fluctuations in response to evapotranspiration, precipitation, changes in stream flows, and groundwater abstraction for irrigation. Of particular interest in the long-term data is the correlation between the responses of near-surface piezometers to pumping events and stream stage fluctuations.

\subsubsection{Subsurface Sampling and Laboratory Analysis}

The subsurface was sampled using a direct-push power probe at 18 locations on the lower floodplain of Scotts Creek. The samples comprised sediment cores $1 \frac{1}{2}$ inches $(3.18 \mathrm{~cm})$ in diameter at depth increments of $1.22 \mathrm{~m}$. The maximum sampling depth achieved was $11 \mathrm{~m}$ below ground surface (bgs). The sampling locations (EB-X) and piezometers (RPX) are indicated on the site map shown in Figure 1. The sediment cores were logged for stratigraphic changes, which revealed the formation to comprise unconsolidated sediment with a layer of clay to fine silt discovered atop the aquifer from a depth of $4.88 \mathrm{~m}$ to $10.7 \mathrm{~m}$ bgs.

Measurement of the particle size distribution of unconsolidated geologic materials is typically used to determine the relative proportions of sand, silt, and clay, but may also be used to estimate porosity and hydraulic conductivity. The particle size distributions of the geologic materials collected from the exploratory boreholes were determined using sedimentation (hydrometer) and dry sieving [30,31]. Twenty-nine samples were selected from exploratory boreholes EB-1-EB-4 for particle size analyses. Samples were carefully selected by visually inspecting the sediment cores and extracting a representative sample from each distinct layer, identified by physical appearance (color) and textural characteristics by feel. As per standard procedure, samples were sieved separately through a No. $10(d \leq 2 \mathrm{~mm})$ sieve to remove rock fragments and soaked overnight in $100 \mathrm{~mL}$ of a dispersing solution (5\% sodium hexametaphosphate $\left.\left(\mathrm{Na}\left(\mathrm{PO}_{3}\right)_{6}\right)\right)$. The samples were additionally dispersed mechanically then quantitatively transferred to separate sedimentation $1 \mathrm{~L}$ cylinders using deionized water. Hydrometer readings of the suspension were collected using an American Society for Testing Materials (ASTM) 152H hydrometer at $40 \mathrm{~s}$, and at 2 and $8 \mathrm{~h}$. Upon completion of hydrometer readings, each sample was wet-sieved and washed thoroughly to discard the silt-clay fraction and retain the sand fraction through a No. $270(\sim 50 \mu \mathrm{m})$ sieve. The retained sand particles were then dry-sieved to further separate them into very coarse, coarse, medium, fine, and very fine sand fractions using a stack of graded sieves with sizes $1 \mathrm{~mm}, 0.5 \mathrm{~mm}, 0.25 \mathrm{~mm}, 0.1 \mathrm{~mm}$, and pan $(0.05<d \leq 0.1 \mathrm{~mm})$. The resulting cumulative particle size distributions were used to estimate saturated hydraulic conductivity using empirical methods available in the hydrology and soil science literature [32,33]. Two of the most commonly used are the Hazen and Kozeny-Carman equations $[10,34,35]$, which have the general form:

$$
K=\frac{\rho g}{\eta} C d_{10}^{2}
$$


where $\rho$ is the density of water, $g$ is acceleration due to gravity, $\eta$ is the dynamic viscosity of water, $n$ is porosity, and $d_{10}$ is the effective grain size. The empirical constant $C$ is given by:

$$
C=6 \times 10^{-4}[1+10(n-0.26)]
$$

for the method of [36], and:

$$
C=\frac{n^{3}}{180(1-n)^{2}}
$$

for the Kozeny-Carman method, which was initially developed by [37] and later modified by [38]. We used these two methods to estimate sediment saturated hydraulic conductivity from particle size distribution data.

In addition to estimates from particle size analysis, permeameter tests are the standard laboratory procedure performed to measure the hydraulic conductivity, $K$, of sediments taken from the field [10,39]. A falling-head permeameter was used to measure the hydraulic conductivity of sediment samples from the exploratory boreholes to characterize the spatial variability of hydraulic conductivity in the alluvial aquifer system. Two flow cells (permeameters) of diameters $3.81 \mathrm{~cm}$ and $4.50 \mathrm{~cm}$, and both $15 \mathrm{~cm}$ in length, equipped with $1.5 \mathrm{~cm}$ falling-head tubes were used (Figure 2). Unconsolidated sediment samples were transferred from the plastic collection tubes to the permeameter in $\sim 0.6 \mathrm{~m}$ sections and packed under saturated conditions. Great care was taken to avoid boundary flow along the walls of the flow cell and to remove trapped air from the sediment before measurements were recorded. Experimental runs were preceded by several flushes of the flow cell to remove trapped air before measurements were made. A WIKA pressure transmitter $(4-20 \mathrm{~mA}$, with a range of $0-5 \mathrm{psi}$; $1 \mathrm{psi}=6894.76 \mathrm{~Pa})$ was attached to the permeameter inflow tubing and connected to a Campbell Scientific CR 300 Data-logger to measure the change in pressure over time (minutes) as a dilute solution of calcium chloride $\left(0.005 \mathrm{M} \mathrm{CaCl}_{2}\right)$ was allowed to discharge through the sample. Flow tests were performed in triplicate on each sediment sample to obtain three independent measurements, which were averaged for a single estimate of hydraulic conductivity.

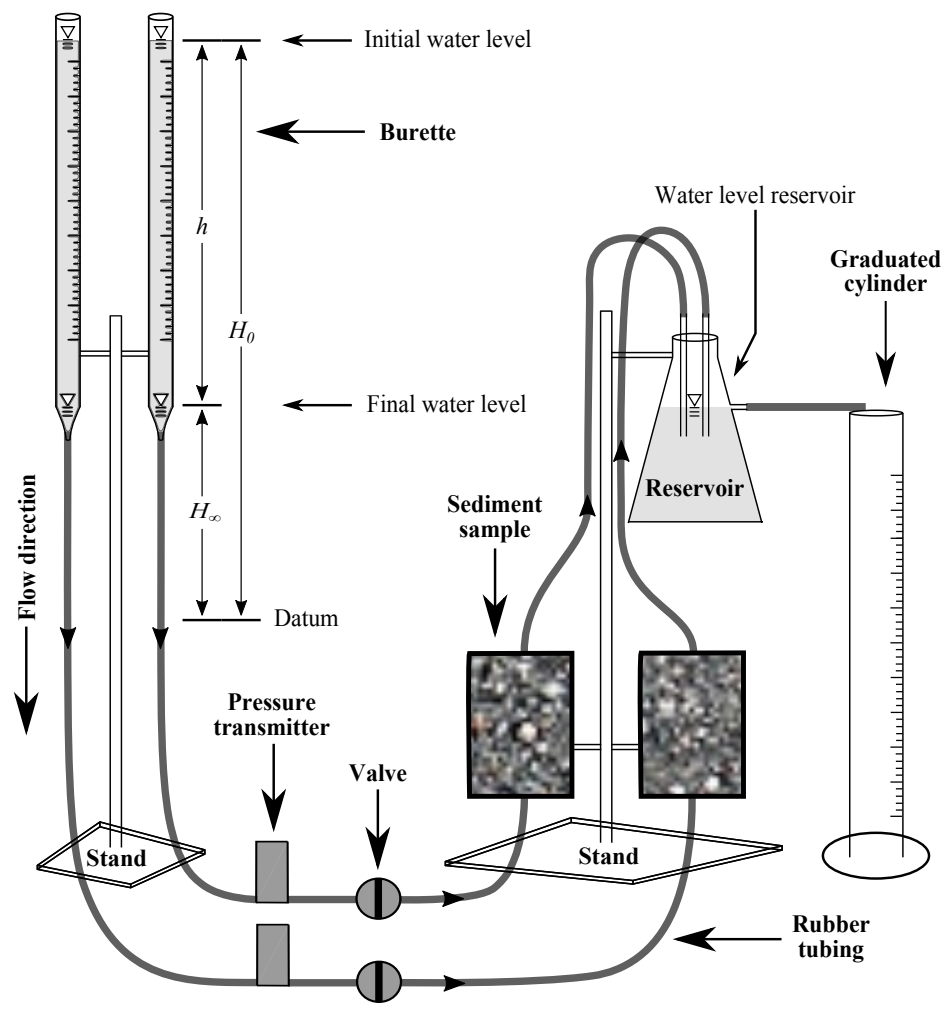

Figure 2. A schematic of the laboratory permeameter setup for permeability testing. 
After each test, the natural logarithm of the normalized hydraulic head data, $\ln \left[h(t) / h_{0}\right]$, was plotted against time, $t$, yielding a straight line passing through the origin. The hydraulic conductivity, $K$, of the sediment was determined from the slope of the line, $m=-1 / \tau_{0}$, where $\tau_{0}=\left(d_{t}^{2} L\right) /\left(d_{s}^{2} K\right), d_{t}$ is the diameter of falling-head tube, and $d_{s}$ is the diameter of the sediment sample of length $L$. Permeameter tests were performed on all sediments collected from exploratory boreholes EB-1-EB-4. For boreholes EB-5-EB-8, only the range in saturated hydraulic conductivity of sediments from each borehole was determined by performing tests on fine- and coarse-grained sediment samples.

\subsubsection{Resistivity Survey}

An electrical resistivity survey was conducted in the study area to investigate the spatial continuity and extent of the sediment layers observed in exploratory boreholes. The resistivity surveys were conducted along three profiles in the vicinity of the creek. Each survey was collected in the dipole-dipole configuration with 56 electrodes spaced at $2 \mathrm{~m}$ intervals along the $A A^{\prime}$ profile and $2.5 \mathrm{~m}$ intervals along the $B B^{\prime}$ and $C C^{\prime}$ profiles. The surveys were conducted with a SuperSting R8 electrical resistivity meter by AGIUSA, along three profiles in the vicinity of Scotts Creek, which are marked on the site map in Figure 1.

\subsubsection{Pumping Tests}

Two pumping tests were conducted in the summer of 2016 in wells AG2 and AG3 (see Figure 1) for the purposes of determining aquifer hydraulic properties, measuring leakage across the aquitard, and detecting stream depletion. The transient drawdown and recovery response of the aquifer system were monitored in the pumping wells, piezometers, and observation wells. Prior to each test, a period of quiescence was observed during which no pumping activity for irrigation occurred. This allowed the system to be at a relatively unperturbed initial state free of the effects of known pumping and percolation of water applied at the surface. The first test was initiated on 1 August 2016 in well AG3, which was pumped at a constant rate of $268 \mathrm{gpm}\left(1.69 \times 10^{-2} \mathrm{~m}^{3} / \mathrm{s}\right)$ for $24 \mathrm{~h}$, after which the system was allowed to recover for two days (gpm is gallons per minute). The response of the aquifer was monitored using pressure transducers installed in the pumping well and in three observation wells marked AG1, AG2, and AG4 in Figure 1. The pressure transducer in the pumping well was installed at a depth of $20 \mathrm{~m}$ below the static water level in the well. In the observation wells, the pressure transducers were installed at depths of $2 \mathrm{~m}$ below the respective static water levels. Vented pressure transducers (INW PT2X Smart Sensor with $\pm 0.05 \%$ full-scale output (FSO) typical error and $\pm 0.1 \%$ FSO maximum error) were used in all the wells and piezometers. The second pumping test was conducted in well AG2 starting on 5 August 2016 following the two-day recovery period from the first test. The well was pumped at an average rate of $254 \mathrm{gpm}\left(1.60 \times 10^{-2} \mathrm{~m}^{3} / \mathrm{s}\right)$ for $24 \mathrm{~h}$. The response of the aquifer was monitored in observation wells AG1, AG3, and AG4. During both pumping tests, leakage from the aquitard was monitored in five piezometers installed in the unconfined aquifer and aquitard. Piezometers were installed in a select few of the exploratory boreholes after retrieval of sediment samples. They were constructed with Schedule 40 PVC casing with a diameter of $2.54 \mathrm{~cm}$ and a screen interval of $0.305 \mathrm{~m}$ at the base. Some of the piezometers were installed in the low permeability silt-clay aquitard layer (e.g., RP4) to monitor leakage during pumping, and others were installed immediately above the aquitard (e.g., RP1) and showed a relationship with streamflow. 
Table 1. Well construction data for irrigation wells used in this study. Screened intervals are measured from the top of steel casing. The dash (-) indicates that data are not available.

\begin{tabular}{cccc}
\hline Well ID & Diameter $(\mathbf{c m})$ & Total Depth $(\mathbf{m})$ & Screen Interval $(\mathbf{m})$ \\
\hline AG1 & 20.32 & 33.5 & $4.6-32.0$ \\
AG2 & 20.32 & 33.5 & $18.3-33.5$ \\
AG3 & 30.48 & 33.5 & $15.2-33.5$ \\
AG4 & 15.24 & - & - \\
\hline
\end{tabular}

Stream stage and discharge response to pumping were monitored using, respectively, pressure transducers in piezometers installed in the stream, and using a dye tracer [40-42]. The instream piezometers comprised standing 1 inch $(2.54 \mathrm{~cm})$ diameter Schedule 40 PVC tubes mounted to posts embedded in the streambed. Instream piezometers were equipped with non-vented absolute pressure transducers (HOBO U20L Water Level Logger with $\pm 0.1 \%$ FSO typical error and $\pm 0.2 \%$ FSO maximum error) for continuous monitoring of the stream stage. A HOBO U20L Water Level Logger was deployed above the water in the shade to monitor barometric pressure changes. The fluorescent dye Rhodamine WT (20\% by mass) was injected directly and continuously into the center of the stream channel about $100 \mathrm{~m}$ upstream of the pumping well. Dye injection, at a constant rate of $10 \mathrm{~mL} / \mathrm{min}$, was initiated $24 \mathrm{~h}$ prior to the onset of pumping to establish a steady-state background concentration. Tracer concentration and temperature $\left({ }^{\circ} \mathrm{C}\right)$ were monitored at 5 min intervals using a fluorometer (Precision Measurement Engineering Cyclops-7 Logger) placed in the middle of the stream channel about $200 \mathrm{~m}$ downstream of the injection point. A steady-state background concentration of around 24 parts per billion (ppb) Rhodamine WT was achieved in the stream prior to initiation of each pumping test. Additionally, effluent from the pumping well was monitored for dye breakthrough. Effluent samples were collected at $15 \mathrm{~min}$ intervals over the course of the pumping tests.

\subsubsection{Long-Term Passive Water Level Monitoring}

In addition to monitoring aquifer and stream response during the pumping tests described above, water levels in three piezometers (RP1, RP4, and RP5) and three irrigation wells (AG1, AG2, and AG3) were passively monitored at 15 min intervals for a continuous period of 18 months from June 2016 to November 2017. During the passive monitoring phase, there was no attempt to control the pumping in the manner described in the preceding section. The agricultural operations, including abstraction and irrigation schedules, were left to proceed as per the usual practice of the farm managers. The objective was to assess correlation in the long-term time series data record among water level fluctuations in the aquifer system and stream stage in response to groundwater pumping, evapotranspiration, and precipitation events.

During the passive period, stream-aquifer connectivity was additionally investigated using dye slug tests. Thirty-six dye slug injections were completed in September 2016 on a $30 \mathrm{~m}$ reach of lower Scotts Creek adjacent to well AG2 over a period of nine days. The tests were performed each day at four hour intervals. Each test, from slug injection to complete measurement of dye concentration downstream, lasted about $20 \mathrm{~min}$. It consisted of near-instantaneous emptying a $250 \mathrm{~mL}$ bottle of Rhodamine WT dye solution, with a concentration of $2.5 \mathrm{~mL} / \mathrm{L}$, into the stream in the middle of the stream channel upstream of the well. Tracer concentrations were measured in the stream at $5 \mathrm{~s}$ intervals with a fluorometer placed $30 \mathrm{~m}$ downstream of the injection point. The injection and measurement locations were the same for all thirty six slug tests.

\section{Results}

\subsection{Subsurface Structure}

Sediment samples logged during direct-push drilling and sampling of the near-surface above the main aquifer formation revealed a layered mixture of unconsolidated sedi- 
ment including gravels, sands, silts, and clays, with variable layer thicknesses, grain size, and sorting. Examples of such sediment cores collected at the site are shown in Figure 3. Generally, the subsurface was found to comprise three layers, namely a layer of brown sand and gravel from the land surface to a depth of about $5 \mathrm{~m}$, underlain with a thin aquitard layer of gray to black silt-clay between depths of 5 and $10 \mathrm{~m}$, which was in turn underlain with a clean sand and gravel layer. The aquitard layer was encountered in all 18 exploratory boreholes, which suggests that it is pervasive and laterally continuous across the study site. The surface sand and gravel layer was found to be a thin unconfined aquifer with the water table at about a $2 \mathrm{~m}$ depth below the land surface. The aquitard layer was also found to be fully saturated. Heaving of sediment occurred when the drilling tooling breached through the silt-clay layer into the main sand and gravel aquifer layer, because of the higher fluid pore pressures in the underlying confined aquifer.

In all boreholes (EB-1-EB-8), measurable saturated hydraulic conductivity values varied by at least an order of magnitude (Table 2).
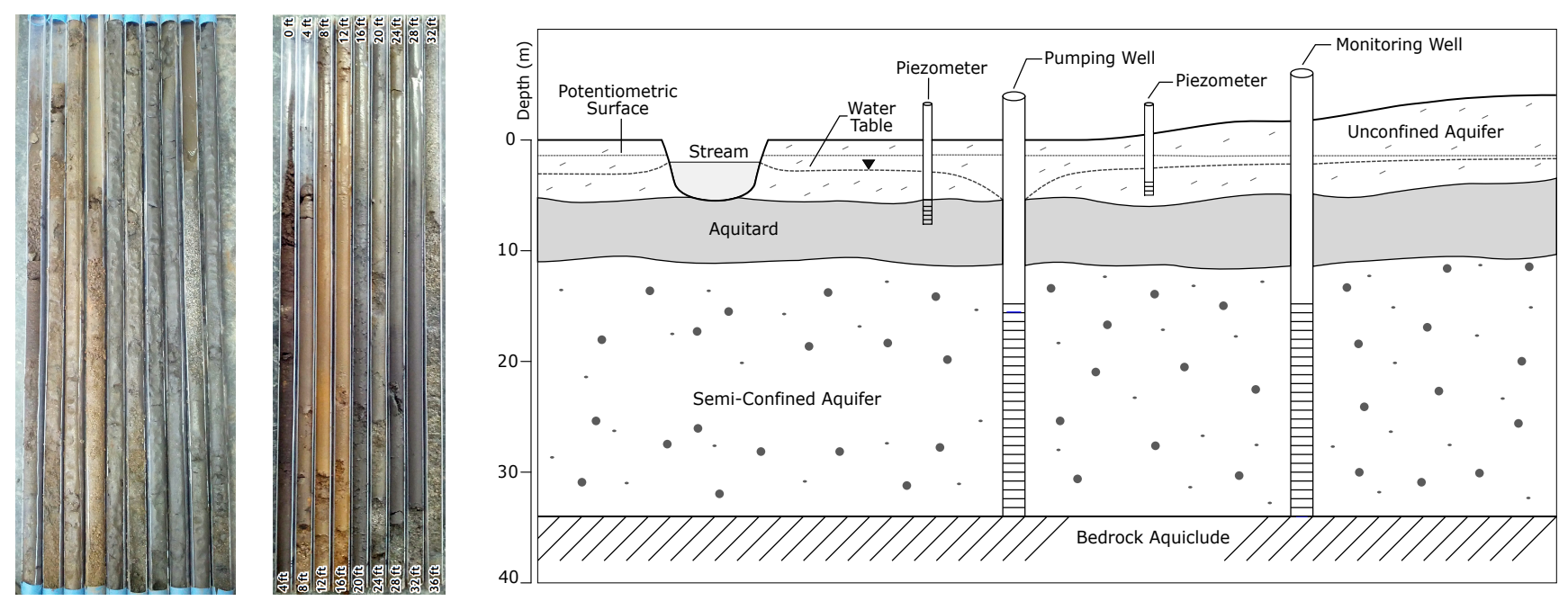

Figure 3. Core samples of subsurface sediment collected from two exploratory boreholes (EB-5 and EB-8) at the study site and the schematic of the three layer conceptual model of the subsurface deduced from analysis of the sediment.

Table 2. Summary of the range in saturated hydraulic conductivity $(K)$ values in $\mathrm{m} / \mathrm{s}$ for sediments from each borehole (EB-1-EB-8) determined using the falling-head permeameter method. The dash $(-)$ indicates that data are not available.

\begin{tabular}{ccc}
\hline Borehole ID & Low $\boldsymbol{K}$ & High $\boldsymbol{K}$ \\
\hline EB-1 & $1.55 \times 10^{-7}$ & $2.90 \times 10^{-5}$ \\
EB-2 & $2.62 \times 10^{-8}$ & $2.22 \times 10^{-5}$ \\
EB-3 & $1.86 \times 10^{-7}$ & $3.95 \times 10^{-5}$ \\
EB-4 & $3.21 \times 10^{-8}$ & $7.25 \times 10^{-6}$ \\
EB-5 & $2.82 \times 10^{-8}$ & $4.44 \times 10^{-5}$ \\
EB-6 & $9.99 \times 10^{-8}$ & $8.27 \times 10^{-5}$ \\
EB-7 & - & $6.78 \times 10^{-5}$ \\
EB-8 & $5.74 \times 10^{-8}$ & $5.98 \times 10^{-6}$ \\
\hline
\end{tabular}

A schematic of the three layer conceptual model of the subsurface is shown in Figure 3. The observed structure suggests that Scotts Creek is in direct hydraulic contact with the unconfined aquifer, but is separated from the deeper confined aquifer by a thin siltclay aquitard. The results of the particle size analysis and falling-head permeameter tests shown in Figure 4 indicate an abundance of poorly sorted coarse sediments. In all boreholes, measured saturated hydraulic conductivity values varied by two to three orders of magnitude. Permeameter and particle size analyses confirmed observations made from 
field sediment samples that the shallow subsurface at the site is a three layered system with aquifer layers having hydraulic conductivities that are two to three orders of magnitude greater than that of the intervening aquitard unit. Well completion reports indicated that the alluvial deposit is about $35 \mathrm{~m}$ thick and is bounded below by a basement of low permeability Santa Cruz Mudstone bedrock.

Near-surface electrical resistivity surveys were conducted at the site to assess the presence and lateral continuity of the aquitard unit beyond the exploratory borehole locations (Figure 1). A comparison of the measured apparent resistivity and calculated resistivity data is included in Appendix A (see Figure A1). The low resistivity feature $(<30 \Omega \cdot \mathrm{m})$ in the depth range of $3 \mathrm{~m}$ to $5 \mathrm{~m}$ along transects $A-A^{\prime}, B-B^{\prime}$, and $C-C^{\prime}$ is interpreted to be the silt and clay aquitard observed in the sediment cores of the exploratory boreholes. The $A-A^{\prime}$ inverted electrical resistivity section shown in Figure 5 shows evidence of the silt and clay aquitard layer on the $A^{\prime}$ side of the profile, which is near exploratory borehole EB-1 (Figure 1). The aquitard is more laterally continuous in transects $B-B^{\prime}$ and $C-C^{\prime}$, with a significantly thicker section in the $C-C^{\prime}$ profile. The higher resistivity values in the $3 \mathrm{~m}$ to $5 \mathrm{~m}$ depth interval in the $A-A^{\prime}$ profile are attributed to the presence of thin sand deposits inter-layered with silt and clay from relatively recent sediment deposition by Scotts Creek. The presence of sand and gravel interbeds in the $A-A^{\prime}$ profile may be due to the high energy depositional environment in the vicinity of the stream channel. The aquitard structure sampled by the three electrical resistivity profiles suggests that it is pervasive, but discontinuous across the study site, indicating a complex history of stream meandering and depositional energy. The base of the aquifer is not detected in the electrical resistivity profiles, the image of which is between $24 \mathrm{~m}$ and $32 \mathrm{~m}$ in depth. Many discrete higher resistivity features $(>50 \Omega \cdot \mathrm{m})$ are observed beneath the aquitard and are possibly sand and/or gravel channels from historical stream meanders across the floodplain.

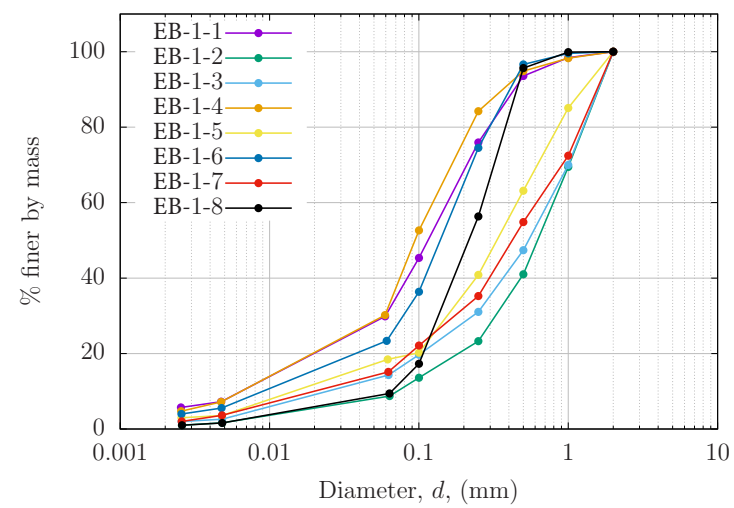

(a)

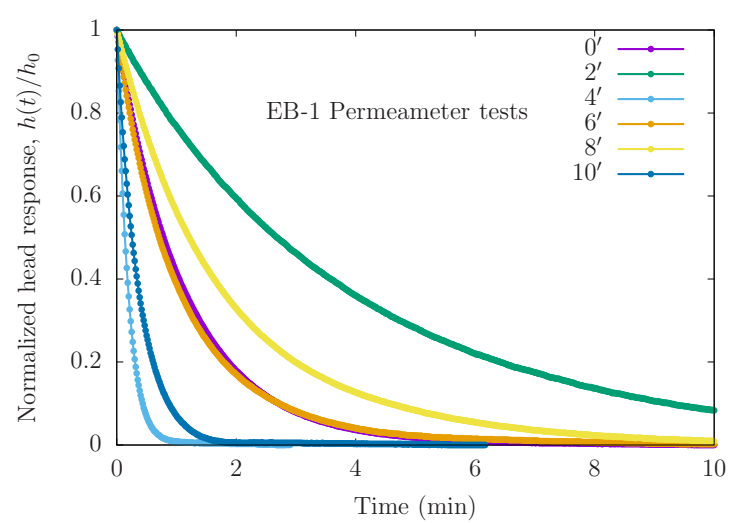

(b)

Figure 4. Examples of laboratory data collected during (a) particle size analyses and (b) falling-head permeameter tests performed on sediment from exploratory borehole EB1.

\subsection{Aquifer-Aquitard Drawdown Response}

Pumping tests conducted in the irrigation wells at the site induced transient responses in observation wells installed in the aquifer and in piezometers installed in the aquitard overlying the aquifer. Pumping rate data for one of the two pumping tests and example drawdown responses measured in observation wells and piezometers are shown in Figure 6. The figure shows the pumping rate for the AG2 well and drawdown data from (a) observation wells AG1, AG3, and AG4 and (b) piezometer RP1. Well AG3 recorded the largest drawdown during this test, being closest to the pumping well at a distance of $260 \mathrm{~m}$. For the second test, with AG3 as the pumping well, observation wells AG2 and AG4, which are almost equidistant from the pumping well (AG3), recorded comparable responses. Well AG1 did not record a measurable drawdown response for this test. It 
should be noted that the response of well AG3 to pumping from AG2 was much larger than that recorded in AG2 when pumping from AG3. This is partly attributable to the modest difference in pumping rates during the two tests. The asymmetry in response may also be attributable to their relative proximity to the stream, the relative thickness of the confining unit in the vicinity of the two wells, and possibly differing wellbore skin effects.

Compared to the aquifer observation wells, piezometers installed in the aquitard, despite their closer proximity to the pumping well, showed only modest responses to pumping. For example, the peak drawdown measured in piezometers was about $5 \mathrm{~cm}$ (in piezometers RP1 and RP4) during pumping from well AG2. The responses of the piezometers were also appreciably delayed relative to those of the observation wells. Piezometers RP1 and RP4 are separated from the pumping well AG2 by radial distances of $18 \mathrm{~m}$ and $28 \mathrm{~m}$, respectively, whereas the distance between well AG2 and observation well AG3 is $260 \mathrm{~m}$. The delays in response were particularly pronounced during the recovery phase. The piezometer data also show that a diurnal signal due to evapotranspiration (ET) by riparian vegetation is superposed with the drawdown response (see the recovery phase of piezometer drawdown in Figure 6b). The groundwater response to ET in the aquitard appears to be much smaller than that due to pumping. The fact that measurable drawdown from aquifer pumping was observed in aquitard piezometers is an indication of leakage from and across this layer into the aquifer during pumping.

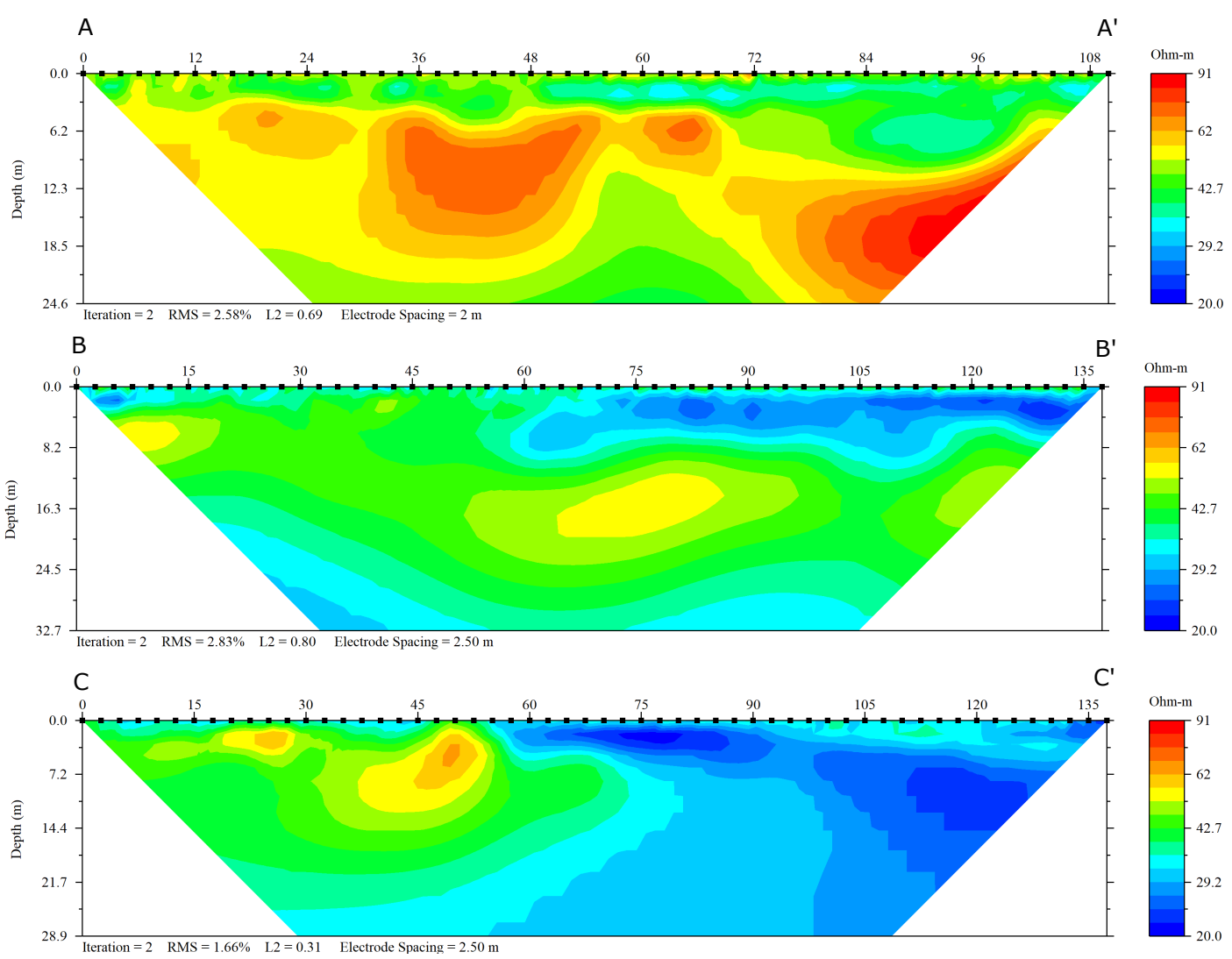

Figure 5. Inverted electrical resistivity tomography profiles in lower Scotts Creek. All data were collected with a SuperStingR8 electrical resistivity meter and processed with EarthImager2D software. Each profile consisted of 56 electrodes spaced at $2 \mathrm{~m}$ in $A-A^{\prime}$ and $2.5 \mathrm{~m}$ in $B-B^{\prime}$ and $C-C^{\prime}$. Profiles $A-A^{\prime}$ and $B-B^{\prime}$ were collected with a dipole-dipole array geometry and profile $C-C^{\prime}$ with a Schlumberger array geometry. The inverted data for all three profiles are plotted on a common color scale. Inversion iteration number, RMS misfit, and L2 misfit are shown beneath each panel. Dimensions of the figure panels vary, but are plotted without vertical exaggeration. 


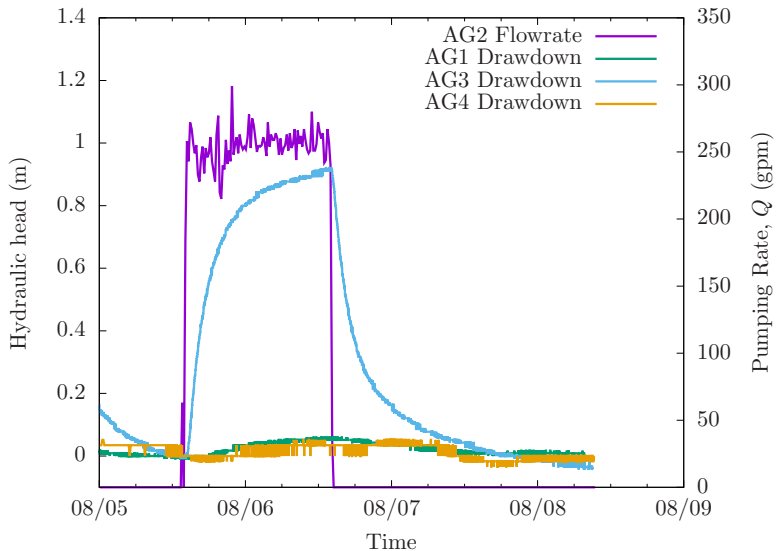

(a)

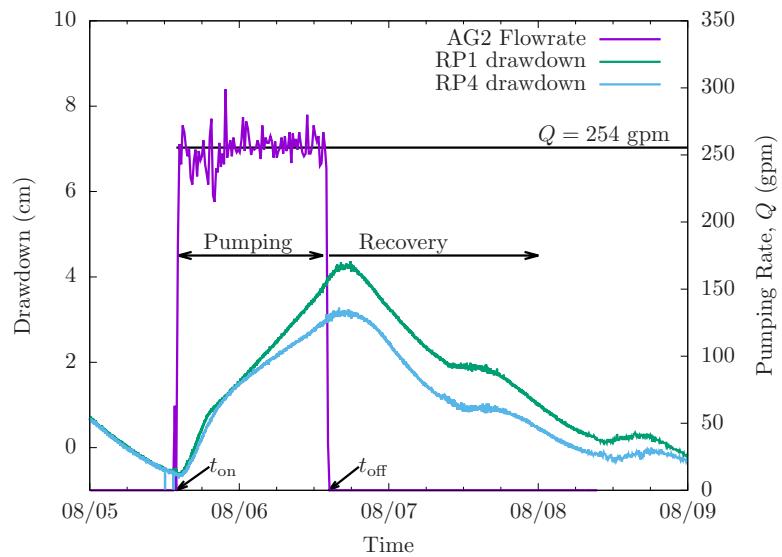

(b)

Figure 6. Drawdown responses observed in selected (a) aquifer observation wells and (b) aquitard piezometers during the second pumping test $\left(Q=254 \mathrm{gpm}=1.60 \times 10^{-2} \mathrm{~m}^{3} / \mathrm{s}\right)$ conducted at Swanton Pacific Ranch in August 2016. The pumping and recovery time periods are marked in $(\mathbf{b})$.

\subsection{Analysis of Aquifer Drawdown Response}

Drawdown data collected in the observation wells were analyzed to determine aquifer hydraulic properties. Initial analysis was performed with the model of Theis [12] and the approximation of Cooper and Jacob [43]. Figure 7 shows the results of the model fits to drawdown data. Although the hydraulic parameter estimates obtained using the solutions of Theis [12] and Cooper and Jacob [43] are comparable to those from laboratory permeameter tests and particle size analysis results, it is clear that both solutions deviate appreciably from the observed drawdown response late-time. The deviation is attributed to vertical leakage contributions to flow in the pumped aquifer. The solution of Hantush and Jacob [44] for classical leakage in confined aquifers was used to improve model fits to data and to obtain improved estimates of aquifer hydraulic parameters.
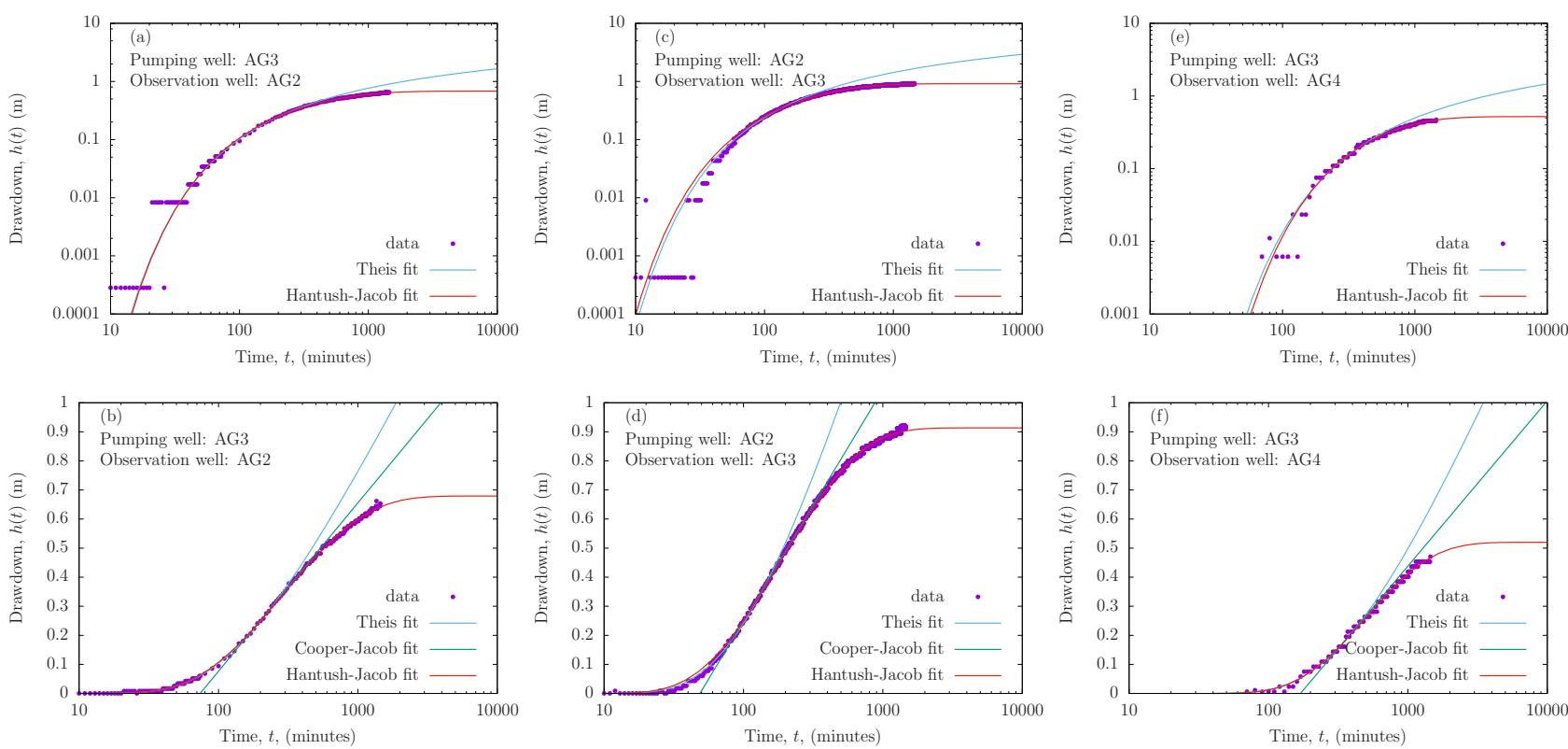

Figure 7. Model fits to drawdown data on log-log (left) and semi-log (right) scales. The effect of leakage is clearly evident at late-time. Here the top graphs are on log-log scale and the bottom graphs are on semi-log scale. Respectively, (a,b) show drawdown in well AG2 due to pumping in well AG3, (c,d) drawdown in AG3 due to pumping in AG2, and (e,f) drawdown in AG4 due to pumping in AG3. 
The results of the model fits of Hantush and Jacob [44] to drawdown data are included in Figure 7. A significant improvement in model fits at late-time is achieved over the model of Theis [12] and the corresponding approximation of Cooper and Jacob [43]. Estimates of the hydraulic parameters are included in Table 3. A comparison of these estimates to laboratory measured values is provided in Table 4. Estimates from laboratory measurements are on average less than the values determined from the analysis of pumping test drawdown data. This is to be expected from the three-dimensional nature of flow at the field scale. However, there is general agreement between lab- and field-based measurements of hydraulic conductivity respecting the subsurface hydrogeologic structure. They all indicate a three layered system of an unconfined aquifer separated from a confined aquifer by a thin aquitard layer. The field-measured values are the most reflective of the in situ permeability reality and are the most relevant to the assessment of stream-aquifer interactions. This also implies the need to use in situ permeability measurement methods, such as direct-push pneumatic slug tests, that can capture the lateral heterogeneity of the subsurface system. Of the laboratory methods, permeameter measurements yielded values that are closer to the values from pumping tests for all three layers. Aquitard permeability values estimated from particle size analysis where about an order of magnitude higher. Hence, stream depletion assessment based on permeability estimates from particle size analysis may overestimate the effects of groundwater abstraction on stream flows.

Table 3. Model estimates of hydraulic parameters from aquifer drawdown data.

\begin{tabular}{lcccc}
\hline Model & Well Pair & $\boldsymbol{K}(\mathbf{m} / \mathbf{s})$ & $\boldsymbol{S}_{\boldsymbol{s}}\left(\mathbf{m}^{-\mathbf{1}}\right)$ & $\boldsymbol{K}^{\prime} \mathbf{( m / s )}$ \\
\hline \multirow{3}{*}{ Theis } & AG3-AG2 & $1.61 \times 10^{-4}$ & $4.40 \times 10^{-5}$ & - \\
& AG3-AG4 & $1.56 \times 10^{-4}$ & $6.70 \times 10^{-5}$ & - \\
& AG2-AG3 & $1.14 \times 10^{-4}$ & $1.80 \times 10^{-5}$ & - \\
\hline \multirow{3}{*}{ Jacob-Cooper } & AG3-AG2 & $2.28 \times 10^{-4}$ & $3.20 \times 10^{-5}$ & - \\
& AG3-AG4 & $2.63 \times 10^{-4}$ & $4.80 \times 10^{-5}$ & - \\
& AG2-AG3 & $1.55 \times 10^{-4}$ & $1.30 \times 10^{-5}$ & - \\
\hline \multirow{3}{*}{ Hantush- } & AG3-AG2 & $1.57 \times 10^{-4}$ & $4.06 \times 10^{-5}$ & $3.57 \times 10^{-8}$ \\
Jacob & AG3-AG4 & $7.80 \times 10^{-5}$ & $4.70 \times 10^{-5}$ & $9.47 \times 10^{-8}$ \\
& AG2-AG3 & $7.30 \times 10^{-5}$ & $1.50 \times 10^{-5}$ & $6.12 \times 10^{-8}$ \\
\hline
\end{tabular}

Table 4. Comparison of laboratory-measured values $K$ to estimates from pumping test data. Hazen and Kozeny-Carman values are based on laboratory particle size analysis.

\begin{tabular}{lcccc}
\hline & \multicolumn{3}{c}{ Hydraulic Conductivity (m/s) } \\
\cline { 2 - 5 } Layer & Hazen & Kozeny-Carman & Permeameter & Pumping Test \\
\hline Unconfined Aquifer, $K_{u}$ & $2.32 \times 10^{-5}$ & $1.40 \times 10^{-5}$ & $3.98 \times 10^{-6}$ & - \\
Aquitard, $K^{\prime}$ & $6.54 \times 10^{-7}$ & $3.38 \times 10^{-7}$ & $1.37 \times 10^{-8}$ & $6.39 \times 10^{-8}$ \\
Confined Aquifer, $K$ & $1.68 \times 10^{-5}$ & $1.31 \times 10^{-5}$ & $2.33 \times 10^{-5}$ & $1.03 \times 10^{-4}$ \\
\hline
\end{tabular}

\subsection{Stream Response to Pumping}

Given that the aquitard is in direct hydraulic contact with the stream, it stands to reason that observation of drawdown in this layer is an indication that some of the leakage comes from the stream. Leakage comes from aquitard storage and the stream. In fact, for the classical leakage model of [44], one assumes the aquitard has no storage, and as such, leakage is simply the Darcy flux across the aquitard, with the top boundary of the aquitard held at a fixed hydraulic head. For the present scenario, that boundary condition is enforced by the stream stage. Piezometers placed in the stream channel to monitor the stream stage did not show a meaningful response to pumping, which provides empirical justification 
for the Dirichlet (fixed head or stage) boundary condition. Transient drawdown data observed in the aquitard, however, demonstrate the deficiency of the model assumption of no aquitard storage.

The dye tracer method was used during the AG2 well pumping test period in an attempt to detect and measure changes in stream discharge. Additionally, effluent from the pumping well was monitored for dye breakthrough. No dye was detected in the effluent water. This apparently is due to sorption of the dye to subsurface organic materials, which would have required continued pumping beyond the time frame of the field activity as the expected retardation factor is large. Limitations of dye breakthrough monitoring and analysis were addressed in the review article of [42], where it was attributed to sorption and retardation using data from column, batch [45], and field studies [46-48]. Figure 8a shows well-mixed dye across the stream channel. The measured concentrations before, during, and after the AG3 pumping test are shown in Figure 8b, where the thick solid line indicates the average concentration measured during the respective phase of the test. The startand end-time of the pumping phases are also indicated. The raw dye concentrations data show significant fluctuations about the mean. These fluctuations are attributable to natural streamflow variations. A modest increase in average dye concentration above the pre-pumping level was observed toward the end of the pumping test, followed by a modest decrease in average concentration after cessation of pumping. The increase in concentration observed during the pumping phase showed a time lag of about $18 \mathrm{~h}$ from the onset of pumping, whereas the decrease in concentration after cessation of pumping occurred at a lag-time of about $6 \mathrm{~h}$. An interruption of dye injection into the stream occurred during the pumping phase when the pump malfunctioned. Hence, the lag-time of the mean concentration increase above background levels may have occurred sooner than the observed value of about $18 \mathrm{~h}$. Generally, the observed changes in mean concentration and the associated lag-times relative to the onset and cessation of pumping are suggestive of a decrease in stream discharge and a weak hydraulic connection between the stream and pumped aquifer. The variance of the background fluctuations in dye concentration time series is relatively high, however, and the observed response is comparable in magnitude to the background fluctuations. For similar pumping conditions, repetitions of the field tests are needed to conclusively ascribe these observations to stream-aquifer exchange, where the increases in concentration of the dye tracer during the pumping period are consistently observed in the test replications. Additionally, the decreases in dye concentrations after cessation of pumping, during the recovery period, would need to be replicated in additional field tests.

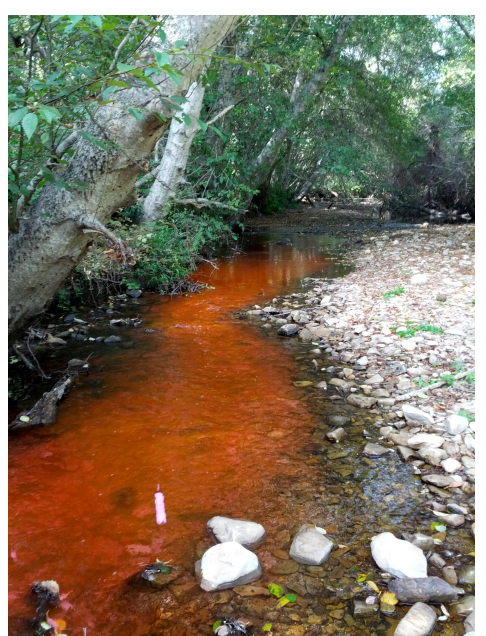

(a)

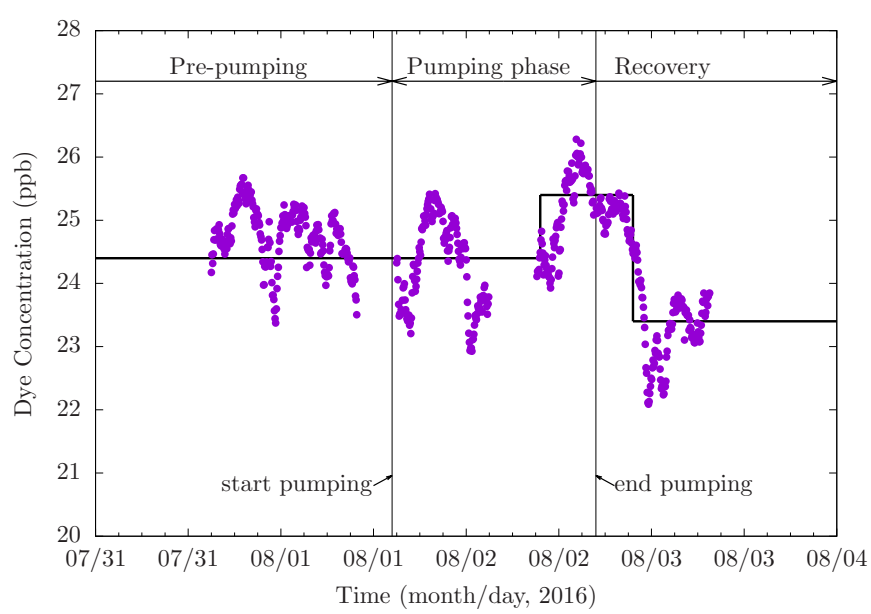

(b)

Figure 8. (a) Rhodamine WT dye in Scotts Creek and (b) measured dye concentration (ppb) in the creek during the pre-pumping, pumping, and recovery phases of the AG3 well pumping test. Average concentration indicated with the piecewise solid line. 
In order to minimize the uncertainty gap in the dye tracer tests, dye slug tests were performed about a month after the pumping tests described above, but during a regular pumping period for irrigation. The data and results of stream discharge estimates are shown in Figure 9. The travel time of the peak concentration from the injection location to the fluorometer ranged from 1 to $5 \mathrm{~min}$, and the stream discharge values ranged from 0.0623 to $0.0821 \mathrm{~m}^{3} / \mathrm{s}$. The two possible interpretations of the results are indicated by piecewiseconstant (solid) and linear decline (dashed) in the mean stream discharge. The former is indicative of stream depletion due to groundwater abstraction; stream discharge during the first five days averaged about $5.66 \times 10^{-3} \mathrm{~m}^{3} / \mathrm{s}$ higher than during the last four days. The lag or delay in the decrease of stream discharge is suggestive of weak stream-aquifer connectivity. Alternatively, the stream discharge may simply have shown a steady linear downward trend over the course of the nine days, indicated in Figure $9 \mathrm{~b}$ by the dashed line, which may be attributable to normal recession of stream flow.

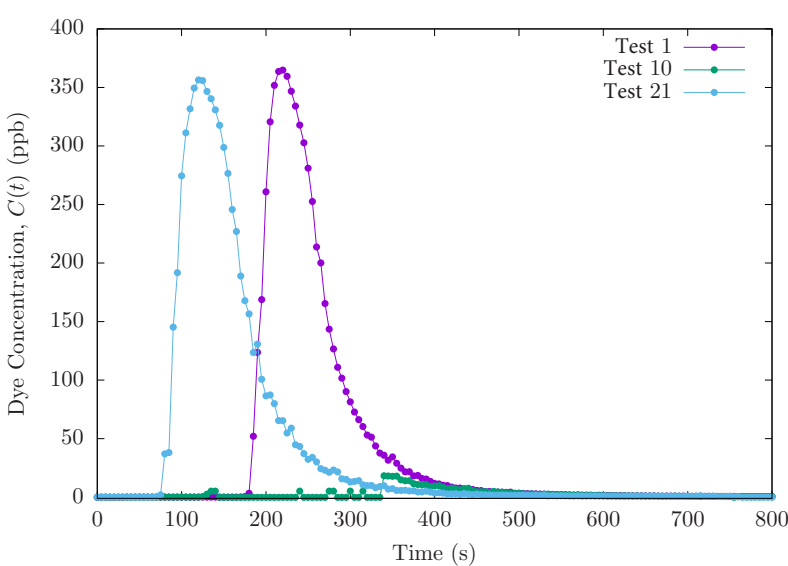

(a)

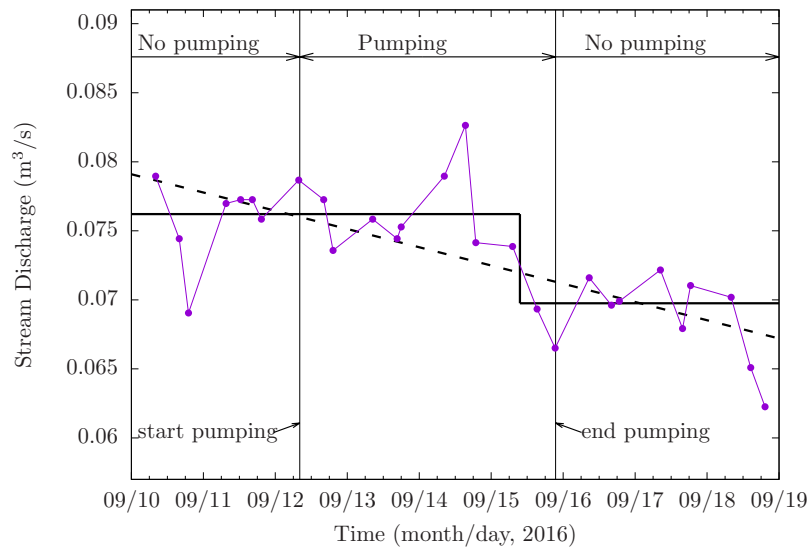

(b)

Figure 9. (a) Examples of observed time-concentration dye slug test data and (b) estimated stream discharge. Two possible interpretations of piecewise constant and steady linear decline in the mean stream discharge are indicated by solid and dashed lines, respectively.

\subsection{Assessment of Stream-Aquifer Connectivity}

Given the uncertainties in dye tracer test results for measuring stream discharge response to pumping, long-term water level monitoring data were collected in aquitard piezometers, aquifer wells, and the stream to evaluate system connectivity. Figure 10 shows water level fluctuation time series in (a) Scotts Creek and (b) piezometer RP1 and well AG2 for a period of over a year extending from August 2016 to November 2017. The monitoring period included the winter precipitation period of 2016-2017. Generally, the observed water level fluctuations are in response to groundwater pumping, evapotranspiration, ocean tide effects, recharge primarily from winter-spring precipitation events, and longterm discharge to the stream and ocean characterized by a period of recession. The three time series show an overall correlation in their global features. They are all responsive to winter precipitation events and have periods of recession that occur from the end of spring through the summer and into the fall. The recession periods are dominated by small water level fluctuations and a general slow decline of water levels. The general correlation among the three time series is indicative of the inter-connectedness of the aquifer-aquitard-stream system and the response of these three components to a common system forcing. 
A close-up of the three time series for the 2016 period between August and October (marked by grey box in Figure 10) is shown in Figure 11. A focus on this shorter time period allows for identification of the dominant hydrologic stresses acting on lower Scotts Creek groundwater levels and the associated responses of the hydrostratigraphic units. Pumping from irrigation wells AG2 and AG3 and evapotranspiration from riparian corridor vegetation are the primary stresses causing the short time fluctuations. Time of onset and cessation of the main pumping events in AG2 clearly correlate to water level declines in RP1. Drawdown occurs during the pumping phases of each pumping event followed by recovery after cessation of pumping. In Figure 11, the responses of well AG2 to pumping from well AG3 are highlighted with the red ellipses, and these clearly map to responses in RP1, albeit of smaller magnitude than those resulting from AG2 pumping. The magnitudes of the induced drawdown, as well as the delayed response of RP1 water levels to the onset and cessation of pumping in irrigation wells are attributable to the relatively low permeability of the aquitard unit. The general decline of the stream stage also appears to match the corresponding general decline in RP1 water levels.

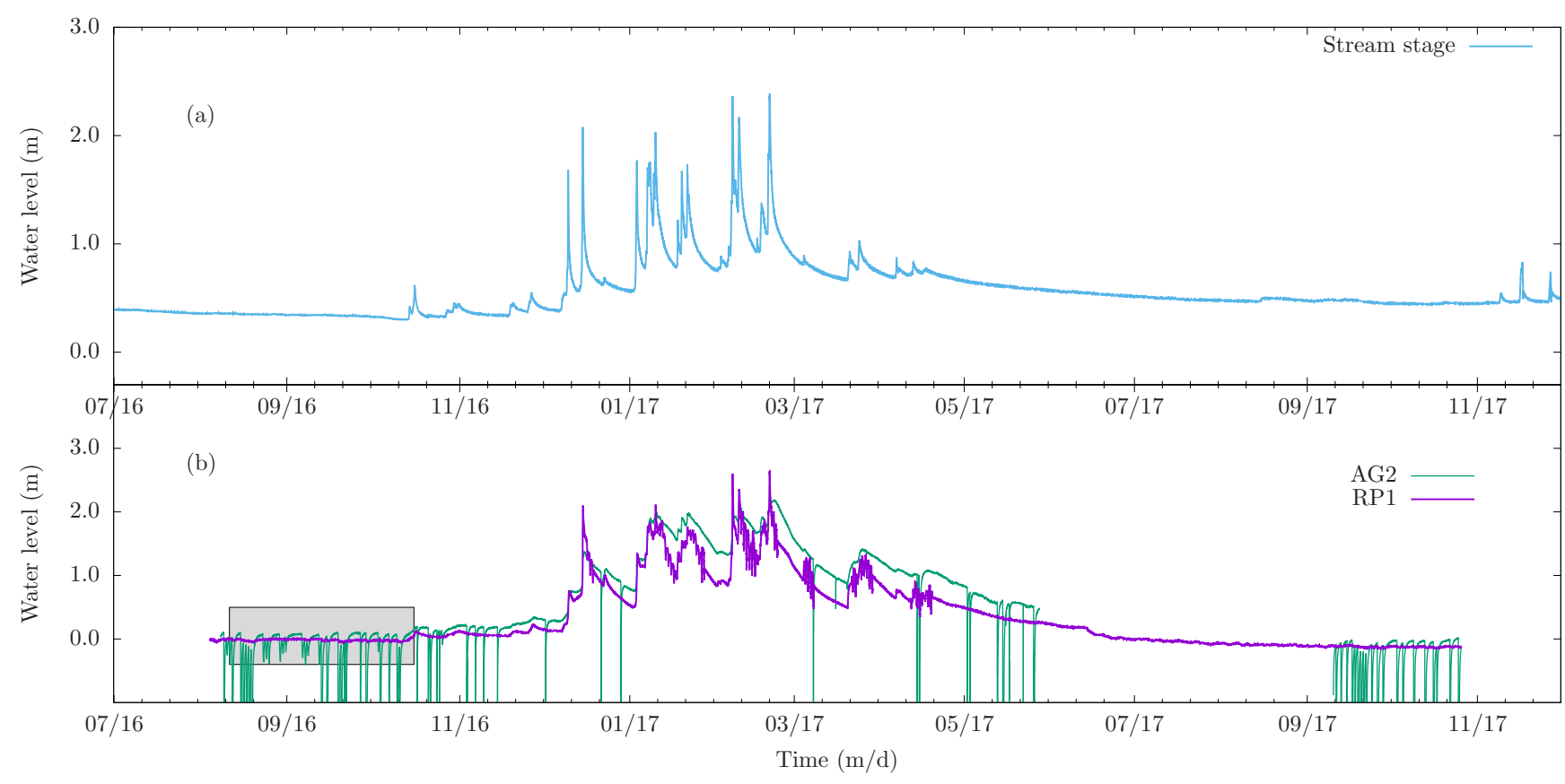

Figure 10. Comparison of water level fluctuations in (a) Scotts Creek and (b) piezometer (RP1) and an irrigation well (AG2), from August 2016 to November 2017. To facilitate comparison, the water levels plotted in (b) were referenced to the first recorded data point in each respective time series. The large drawdown responses $(\geq 15 \mathrm{~m})$ in the top graph are those of well AG2 water levels to pumping in AG2. Data in the gray box are shown in Figure 11 below. 


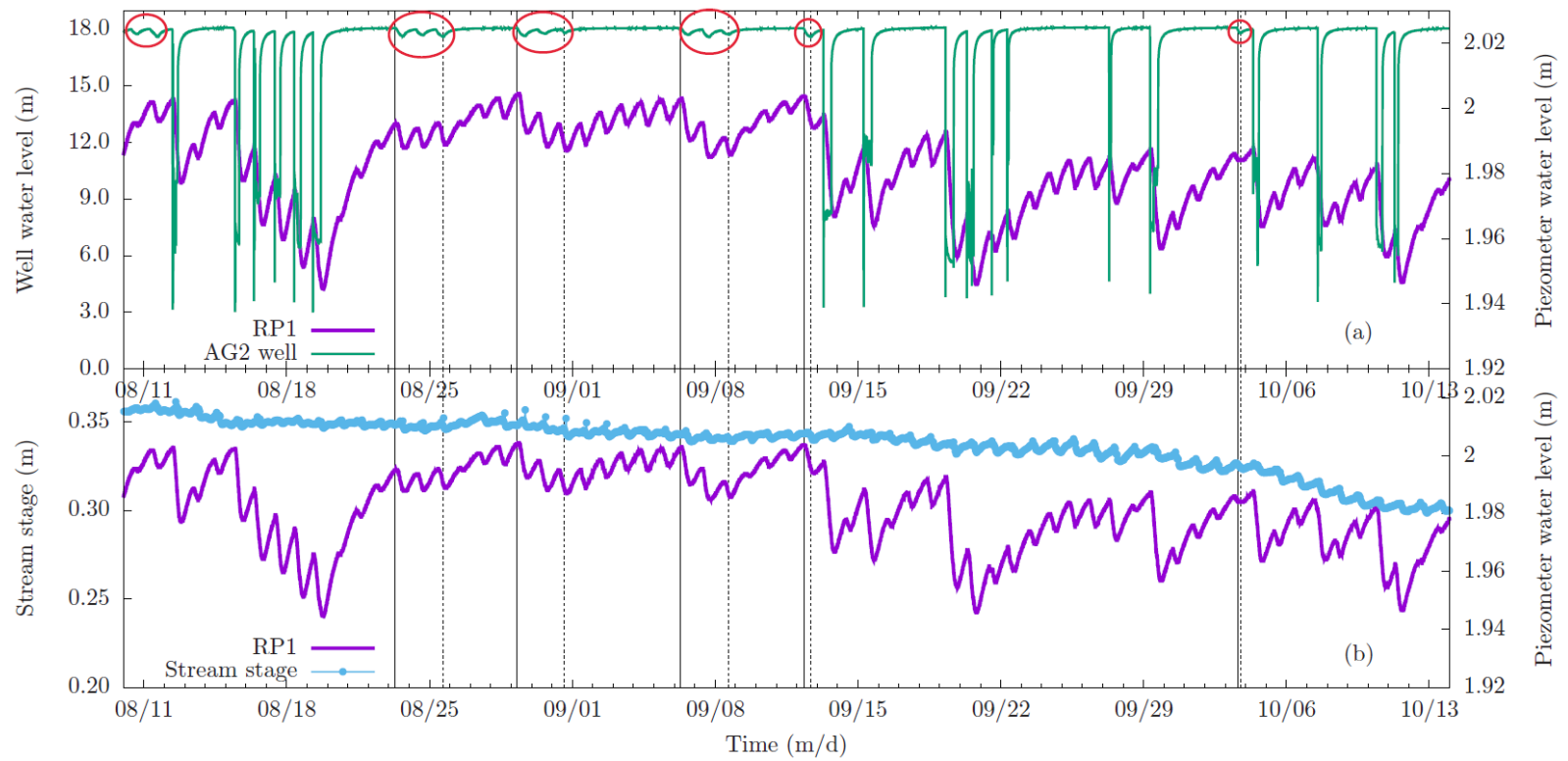

Figure 11. Close-up view of water levels in (a) well AG2 and piezometer RP1, and (b) the stream stage and piezometer RP1 over the period August-October 2016. The large drawdown responses ( $\geq 15 \mathrm{~m})$ in the top graph are those of well AG2 water levels to pumping in AG2, and the ones circled in red are the responses of well AG2 water levels to pumping periods in AG3. The vertical solid (start) and dashed (end) lines mark the AG3 pumping period. The small drawdown responses $(\geq 0.05 \mathrm{~m})$ in the graphs are those of piezometer RP1 water levels to pumping in wells AG2 and AG3 and groundwater uptake by phreatophytic riparian vegetation.

\subsection{Spectral Analysis of Stream-Aquifer Connectivity}

In addition to the response to pumping and precipitation events, the piezometer RP1 water levels show diurnal fluctuations attributable to evapotranspiration. Similar high frequency fluctuations are evident in stream stage data collected in an instream piezometer. Spectral analysis was performed on the RP1 and stream stage data to better understand their frequency content and correlation. To accomplish this, global trends were removed from the data using cubic polynomial fits. Piezometer RP1 and stream stage water level fluctuations, with global trends removed, are shown in Figure 12a,e, respectively. These global trends are attributable to baseflow recession effects. Upon detrending the raw data, the power spectral densities of the time series were computed using the fast Fourier transform (FFT). The power spectra of the two time series are shown in Figure 12c,g, where the spectral density is plotted against frequency in cycles per day (cpd). The dominant or major frequencies, where the power density $\Phi>3 \times 10^{2} \mathrm{~cm}^{2}$ for RP1 data and $\Phi>0.5 \mathrm{~cm}^{2}$ for stream stage data, are highlighted in red. After discarding all the minor frequency components, the reconstructed signal was computed (inverse FFT after discarding minor frequency components) and is included in Figure 12a,e for comparison with the respective original time series. The residuals, computed as the differences between the original and reconstructed time series, are plotted in $(b, f)$. The graphs in $(\mathrm{d}, \mathrm{h})$ show the spectra on a semi-log plot, which allows for the presence of semi-diurnal components, in addition to the diurnal components in both time series, to be further highlighted. 

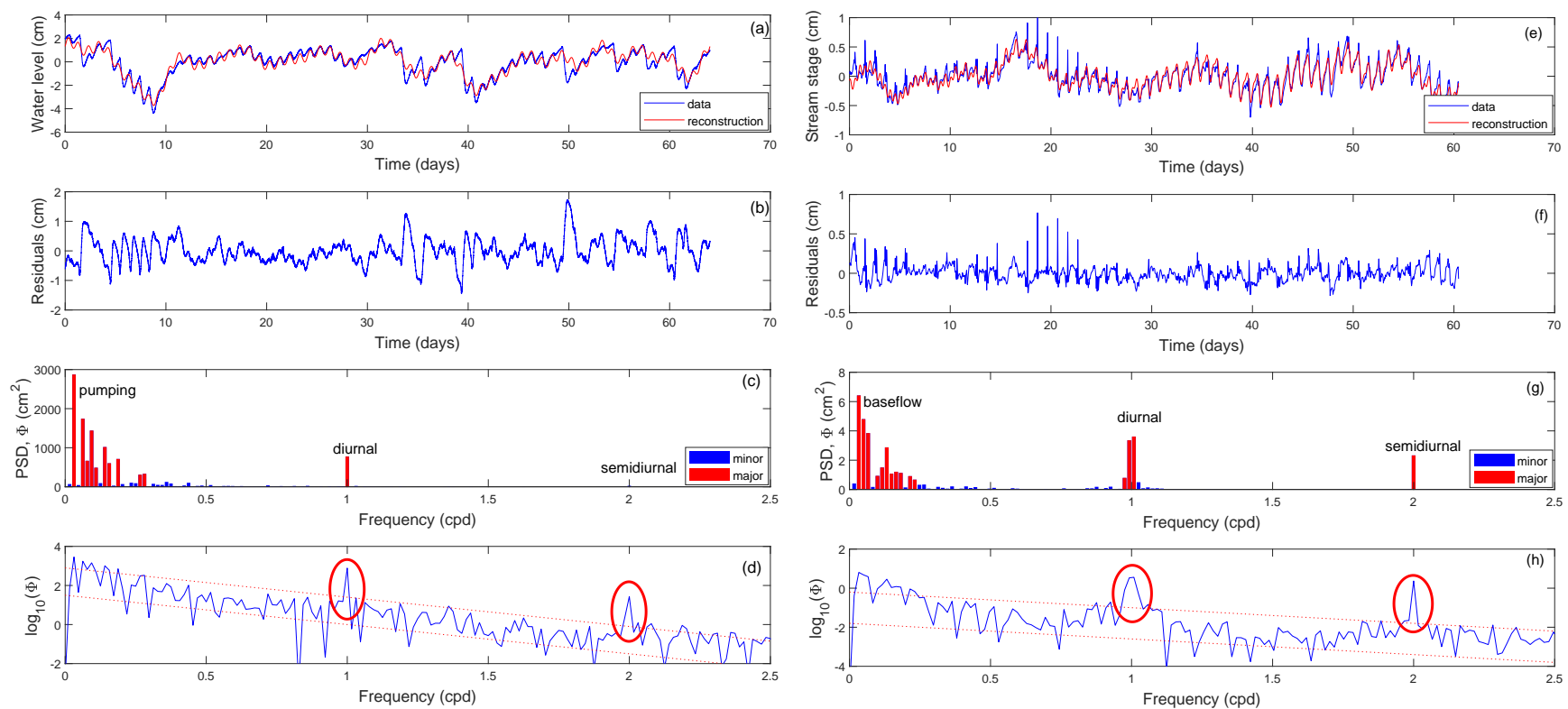

Figure 12. Spectral analysis of piezometer $(\mathbf{a}-\mathbf{d})$ and the stream stage (e-h) water level time series, where (a,e) show water level fluctuations with the mean removed (blue) and filtered (red), $(\mathbf{b}, \mathbf{f})$ time series of residuals (data minus reconstructed signal), (c,g) power spectra with frequencies where $\Phi$ (PSD) exceeds $\Phi_{0}$ marked in red, and (d,h) power spectra plotted on semi-log scale to highlight diurnal and semi-diurnal frequencies (red circles). $\Phi_{0}=3 \times 10^{2} \mathrm{~cm}^{2}$ for RP1 and $\Phi_{0}=0.5 \mathrm{~cm}{ }^{2}$ for the stream stage. The dotted red lines in $(\mathbf{d}, \mathbf{h})$ are $95 \%$ confidence intervals based on linear trend and constant variance.

Both power spectra show a clear diurnal signal (at frequency of $1 \mathrm{cpd}$ ) that primarily comprises evapotranspiration forcing. They also show low frequency components that are due to aquifer groundwater pumping, which induces low frequency effects on stream baseflow. The spectrum for stream stage also has a clear dominant semi-diurnal frequency ( 2 cpd), which suggests that ocean and earth tide effects [49-52] are observable in the stream far upstream along the creek from the estuary on the Pacific coast. The semidiurnal frequency appears minimal in piezometer RP1 data. However, plotting the power spectra on semi-log (power) axes, as shown in (d) and (h), reveals the presence of an unambiguous semi-diurnal component even in piezometer data (diurnal and semi-diurnal frequencies are highlighted with red circles in the figure). The dotted red lines in (d) and (h) are the $95 \%$ confidence intervals based on constant linear trend and variance of the log-transformed power spectra. The peaks observed at 1 and $2 \mathrm{cpd}$ are clearly outside the range of uncertainty attributable to random fluctuations. The semi-diurnal frequency is the the most dominant of all the high frequency (greater than $1.5 \mathrm{cpd}$ ) components in both time series, which suggests that it is not just an aberration. Its presence suggests that tidal effects propagate even in the aquitard layer and that it is induced primarily by stream stage fluctuations. The presence of diurnal and semi-diurnal frequency components in both stream and aquitard water level time series data is indicative of their correlation.

\section{Discussion}

This study examined the influence of groundwater abstraction from an alluvial aquifer on flow in a nearby stream in a Mediterranean climate coastal California watershed. Field investigations and laboratory tests were undertaken to: (1) characterize the alluvial aquifer, (2) establish the degree of hydraulic connectivity between the stream and aquifer, and (3) provide estimates of sustainable groundwater pumping from the irrigation wells at the site. Field investigations revealed a multi-layered and heterogeneous subsurface system comprising a near-surface unconfined aquifer underlain by a thin very low permeability aquitard, which rests above a productive leaky confined aquifer. Irrigation wells are completed in the leaky confined aquifer. Data from field and laboratory tests indicate that the stream and leaky confined aquifer are only weakly connected; water levels in the 
unconfined aquifer connected to the stream exhibit an attenuated and delayed response to groundwater extraction. It is realized, however, that these conclusions are based on the findings of a two-year study. Stresses imposed by changes in climate and water resource needs ought to be examined with rigorous scientific investigations to determine appropriate management strategies.

The results of this work illustrate the importance of employing multiple complimentary methods that cover a range of spatial scales to effectively quantify stream-aquifer interactions in multi-layered leaky systems. Although it would be imprudent to make water resource management decisions based on data collected using a single investigative technique, many applied groundwater-surface water interaction studies lack sufficient funding to integrate multiple types of measurements. Therefore, for the conditions observed herein, we identified the three best methods to inform management decisions with a high degree of confidence. The methods include (1) detailed subsurface sampling, (2) piezometer installation and instrumentation, and (3) pumping tests. Additionally, improvement of these methodologies may include prolonged duration pumping tests to capture late-time leakage, piezometers installed in the streambed to measure vertical hydraulic gradient and streambed hydraulic conductivity, and multi-level or nested piezometers to monitor discrete groundwater zones and to measure variations in hydraulic gradients within the subsurface.

Although the findings indicate that current groundwater abstraction practices have minimal direct impact on Scotts Creek streamflows, during extended periods of abnormally low precipitation, the increased demands on irrigation wells may exacerbate the effects of drought-induced stress on the creek, leading to impaired water quality and quantity. Restricting pumping duration to six hours or less could reduce pumping-induced leakage and allow the aquifer time to recover between pumping events. To compensate for lower volumes of water, the implementation of best management practices and investment in water-efficient irrigation technologies are recommended. To ensure water security under climate uncertainty, it is critical to implement water storage in the form of tanks or a reservoir with abstraction limited to the winter when the stream flows and stage are at their maxima. Limiting pumping duration, implementing best management practices in terms of water distribution efficiency, the use of stored water to supplement groundwater supplies during dry summer months, and the adoption of an adaptive and holistic management approach to account for varying climatic conditions together would minimize economic and environmental concerns surrounding groundwater use on lower Scotts Creek.

\section{Conclusions}

The results of this work illustrate the importance of site-specific investigations to effectively assess stream-aquifer interactions and stream depletion due to groundwater pumping for crop irrigation. The inherent heterogeneous nature of hydrogeologic systems make it challenging to apply general assumptions about their behavior. The site investigated herein was found to be heterogeneous and multi-layered with the stream in direct hydraulic contact with a low permeability unit that separates it from the main water bearing formation used for groundwater abstraction for irrigation. Water level fluctuations in the aquitard layer exhibited relatively small and delayed responses to groundwater extraction during pumping tests. However, the long-term monitoring data show a clear correlation among aquifer pumping events, aquitard head fluctuations, and stream stage water levels. The response of the aquitard water levels to aquifer pumping is indicative of leakage from aquitard storage and across it from the overlying unconfined aquifer layer and the stream. Leakage from and across the aquitard, which is in direct hydraulic contact with both the stream and the aquifer, is an indirect indication of stream-aquifer connectivity. Hence, even for systems where the stream is not in direct hydraulic contact with the producing aquifer, stream depletion may occur over the long term due to leakage across low permeability units. Under the conditions of prolonged drought, this could easily lead to critically low stream flows and dry streambeds. 
Spectral analyses of long time series of both the stream stage and groundwater level fluctuations revealed correlations among system components that were difficult to decipher from short-term pumping tests. This requires instrumentation of streams for stream stage measurement and monitoring, as well as instrumentation of all the pertinent pervasive and laterally extensive layers of the subsurface for groundwater monitoring. Along the California coast, watersheds and associated groundwater systems remain sparsely instrumented, monitored, and poorly characterized, despite their importance for sustaining coastal agriculture, ecosystems, and habitats. Future work will focus on the installation of permanent groundwater monitoring systems, as well as the development of robust numerical groundwater models for heterogeneous subsurface systems to better understand their coupling with stream flows and to better quantify the sustainable rates (yield) of groundwater pumping in such systems.

Author Contributions: Conceptualization, B.M. and D.P.-P.; methodology, B.M. and D.P.-P. (pumping tests, drilling/sampling, laboratory testing) J.J.J. (resistivity survey), and C.S. (dye tracer and slug test design); software, B.M.; validation, B.M. and D.P.-P.; formal analysis, B.M. and D.P.-P.; investigation, D.P.-P.; resources, B.M.; data curation, D.P.-P. and B.M.; writing-original draft preparation, B.M. and D.P.-P.; writing-review and editing, B.M., D.P.-P., J.J.J., and C.S.; visualization, B.M.; supervision, B.M.; project administration, B.M.; funding acquisition, B.M. and C.S. All authors read and agreed to the published version of the manuscript.

Funding: This work was funded by the USDA McIntire-Stennis Program and the California State University (CSU) Agricultural Research Institute (ARI).

Informed Consent Statement: Not applicable.

Data Availability Statement: Relevant data reported herein have been submitted directly to Water.

Acknowledgments: This work was facilitated by Swanton Pacific Ranch (SPR) Director Brian Dietterick, Manager of Operations Steve Auten, SPR staff Grant William and Brian Cook, and student intern Brian Clark.

Conflicts of Interest: The authors declare no conflict of interest.

\section{Abbreviations}

The following abbreviations are used in this manuscript:

$\begin{array}{ll}\text { AG } & \text { Agricultural well } \\ \text { bgs } & \text { Below ground surface } \\ \text { cfs } & \text { Cubic feet per second } \\ \text { cpd } & \text { Cycles per day } \\ \text { EB } & \text { Exploratory borehole } \\ \text { ET } & \text { Evapotranspiration } \\ \text { ERT } & \text { Electrical resistivity tomography } \\ \text { FFT } & \text { Fast Fourier transform } \\ \text { gpm } & \text { Gallons per minute } \\ \text { IP } & \text { Instream piezometer } \\ K & \text { Aquifer hydraulic conductivity }(\mathrm{m} / \mathrm{s}) \\ K^{\prime} & \text { Aquitard hydraulic conductivity }(\mathrm{m} / \mathrm{s}) \\ \text { ppb } & \text { Parts per billion } \\ \text { RP } & \text { Riparian corridor piezometer } \\ \text { SPR } & \text { Swanton Pacific Ranch } \\ S_{s} & \text { Aquifer specific storage }\left(\mathrm{m}^{-1}\right)\end{array}$

\section{Appendix A. Field and Calculated Apparent Resistivity}

For each electrical resistivity profile $\left(\mathrm{A}-\mathrm{A}^{\prime}, \mathrm{B}-\mathrm{B}^{\prime}\right.$, and $\left.\mathrm{C}-\mathrm{C}^{\prime}\right)$, the calculated apparent resistivity from the inverted electrical resistivity data is compared to apparent resistivity field data in Figure A1. 

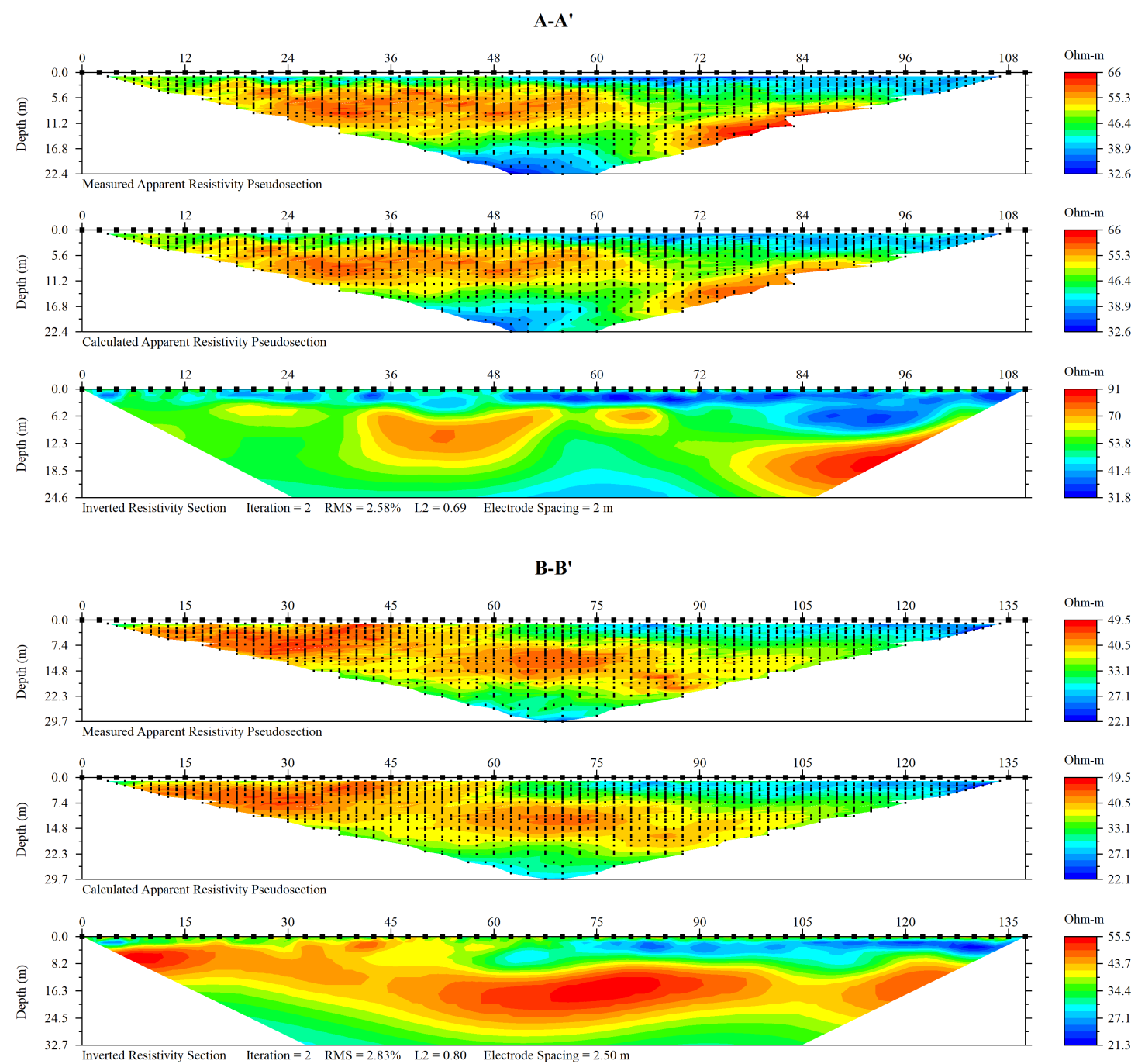

${\mathrm{C}-\mathrm{C}^{\prime}}^{\prime}$
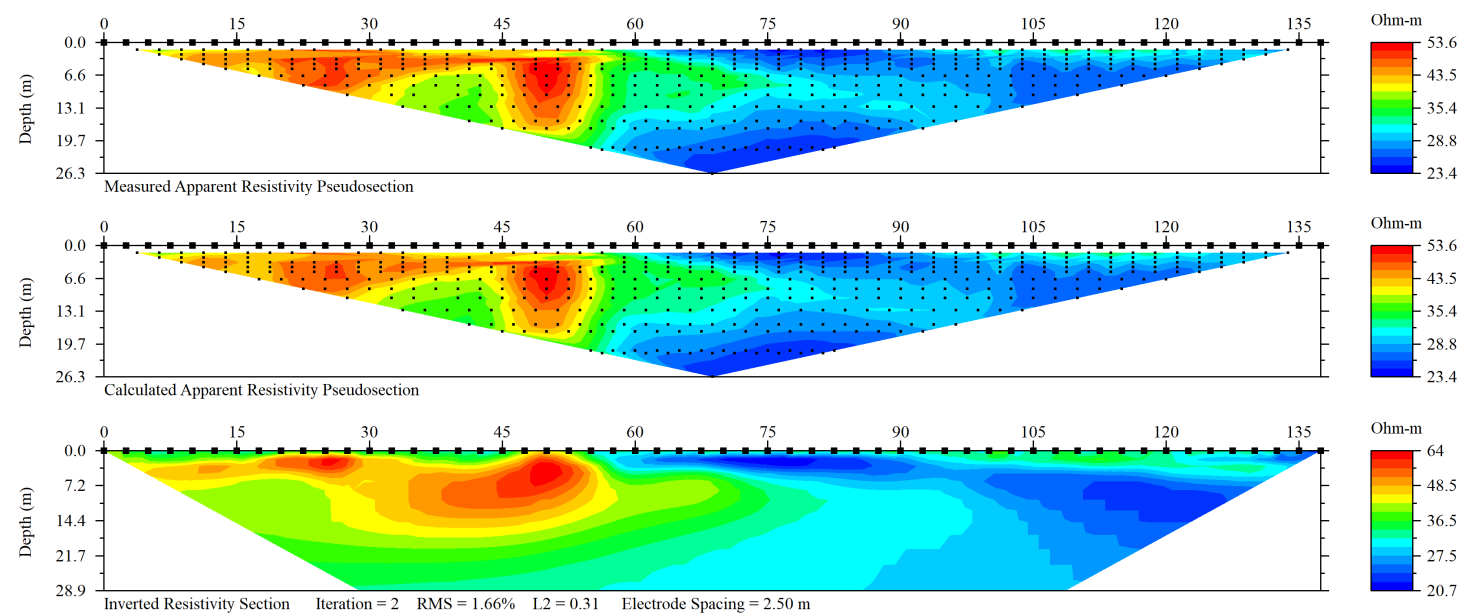

Figure A1. Top panel: apparent resistivity field data. Middle panel: calculated apparent resistivity. Bottom panel: inverted electrical resistivity. Black dots are the position of measured and calculated apparent resistivity data. RMS misfit is less than three percent for all data. Note that the individual profiles are not on a common color scale. 


\section{References}

1. Barlow, P.M.; Leake, S.A. Streamflow Depletion by Wells-Understanding and Managing the Effects of Groundwater Pumping on Streamflow; Circular 1376; US Geological Survey: Washington, DC, USA, 2012; 84p.

2. Stromberg, J.C.; Tiller, R.; Richter, B. Effects of groundwater decline on riparian vegetation of semiarid regions: The San Pedro, Arizona. Ecol. Appl. 1996, 6, 113-131. [CrossRef]

3. Condon, L.E.; Maxwell, R.M. Simulating the sensitivity of evapotranspiration and streamflow to large-scale groundwater depletion. Sci. Adv. 2019, 5, eaav4574. [CrossRef]

4. Konikow, L.F.; Kendy, E. Groundwater depletion: A global problem. Hydrogeol. J. 2005, 13, 317-320. [CrossRef]

5. Deitch, M.J.; Dolman, B. Restoring Summer Base Flow under a Decentralized Water Management Regime: Constraints, Opportunities, and Outcomes in Mediterranean-Climate California. Water 2017, 9, 29. [CrossRef]

6. Ronayne, M.J.; Roudebush, J.A.; Stednick, J.D. Analysis of managed aquifer recharge for retiming streamflow in an alluvial river. J. Hydrol. 2017, 544, 373-382. [CrossRef]

7. McGlochlin, L.M. Aquifer-Stream Interaction in the Lower Carmel Valley, Monterey County, California. Master's Thesis, The University of Arizona, Tucson, AZ, USA, 1984.

8. Kondolf, G.; Maloney, L.; Williams, J. Effects of bank storage and well pumping on base flow, Carmel River, Monterey County, California. J. Hydrol. 1987, 91, 351-369. [CrossRef]

9. Fleckenstein, J.; Anderson, M.; Fogg, G.; Mount, J. Managing surface water-groundwater to restore fall flows in the Cosumnes River. J. Water Resour. Plan. Manag. 2004, 130, 301-310. [CrossRef]

10. Bradbury, K.R.; Muldoon, M.A. Hydraulic conductivity determinations in unlithified glacial and fluvial materials. In Ground Water and Vadose Zone Monitoring; ASTM International: Materials Park, OH, USA, 1990.

11. Kalbus, E.; Reinstorf, F.; Schirmer, M. Measuring methods for groundwater, surface water and their interactions: A review. Hydrol. Earth Syst. Sci. Discuss. 2006, 3, 1809-1850.

12. Theis, C.V. The relation between the lowering of the Piezometric surface and the rate and duration of discharge of a well using ground-water storage. Eos Trans. Am. Geophys. Union 1935, 16, 519-524. [CrossRef]

13. Theis, C. The effect of a well on the flow of a nearby stream. Eos Trans. Am. Geophys. Union 1941, 22, 734-738. [CrossRef]

14. Glover, R.E.; Balmer, G.G. River depletion resulting from pumping a well near a river. Eos Trans. Am. Geophys. Union 1954, 35, 468-470. [CrossRef]

15. Jenkins, C. Techniques for computing rate and volume of stream depletion by wells. Ground Water 1968, 6, 37-46. [CrossRef]

16. Grigoryev, V. The effect of streambed siltation on well-field yield in alluvial aquifers. Water Supply Sanit. 1957, 6, 110-118.

17. Hantush, M.S. Wells near streams with semipervious beds. J. Geophys. Res. 1965, 70, 2829-2838. [CrossRef]

18. Bochever, F. Evaluation of well-field yield in alluvial aquifers: The impact of a partially penetrating stream. Proc. Vodgeo (Hydrogeol.) 1966, 13, 84-115.

19. Zlotnik, V.A.; Huang, H.; Butler, J.J. Evaluation of stream depletion considering finite stream width, shallow penetration, and properties of streambed sediments. In Proceedings of the Water 99: Joint Congress; 25th Hydrology E Water Resources Symposium, 2nd International Conference on Water Resources \& Environment Research; Handbook and Proceedings; Institution of Engineers: Brisbane, Australia, 1999; p. 221.

20. Hunt, B. Unsteady stream depletion from ground water pumping. Ground Water 1999, 37, 98-102. [CrossRef]

21. Butler, J.J.; Zlotnik, V.A.; Tsou, M.S. Drawdown and stream depletion produced by pumping in the vicinity of a partially penetrating stream. Ground Water 2001, 39, 651-659. [CrossRef]

22. Hunt, B. Field-data analysis for stream depletion. J. Hydrol. Eng. 2003, 8, 222-225. [CrossRef]

23. Hunt, B. Stream depletion in a two layer leaky aquifer system. J. Hydrol. Eng. 2009, 14, 895-903. [CrossRef]

24. Butler, J.J., Jr.; Zhan, X.; Zlotnik, V.A. Pumping-induced drawdown and stream depletion in a leaky aquifer system. Groundwater 2007, 45, 178-186. [CrossRef]

25. Boulton, N.S. Analysis of data from non-equilibrium pumping tests allowing for delayed yield from storage. Proc. Inst. Civ. Eng. 1963, 26, 469-482. [CrossRef]

26. Fronzi, D.; Di Curzio, D.; Rusi, S.; Valigi, D.; Tazioli, A. Comparison between Periodic Tracer Tests and Time-Series Analysis to Assess Mid-and Long-Term Recharge Model Changes Due to Multiple Strong Seismic Events in Carbonate Aquifers. Water 2020, 12, 3073. [CrossRef]

27. Tazioli, A.; Colombani, N.; Palpacelli, S.; Mastrocicco, M.; Nanni, T. Monitoring and Modelling Interactions between the Montagna dei Fiori Aquifer and the Castellano Stream (Central Apennines, Italy). Water 2020, 12, 973. [CrossRef]

28. Marston, D. June-July 1992 Stream Survey Report of Lower Scott Creek, Santa Cruz County; California Department of Fish and Game Report; The Resources Agency, Department of Fish and Game: Monterey, CA, USA, 1992.

29. Snider, B.; Urquhart, K.; Marston, D. The Relationship between Instream Flow and Coho Salmon and Steelhead Habitat Availability in Scott Creek, Santa Cruz County; California. CDFG. ESD. Stream Flow and Habitat Evaluation Program; CDFG: Monterey, CA, USA, 1995.

30. ASTM-D6913/D6913M-17. Standard Test Methods for Particle-Size Distribution (Gradation) of Soils Using Sieve Analysis; ASTM International: West Conshohocken, PA, USA, 2017. Available online: www.astm.org (accessed on 15 June 2017). 
31. ASTM-D7928-17. Standard Test Method for Particle-Size Distribution (Gradation) of Fine-Grained Soils Using the Sedimentation (Hydrometer) Analysis; ASTM International: West Conshohocken, PA, USA, 2017. Available online: www.astm.org (accessed on 15 June 2017).

32. Bear, J. Dynamics of Fluids in Porous Media; Dover Publications, Inc.: New York, NY, USA, 1972.

33. Fetter, C.W. Applied Hydrogeology, 4th ed.; Prentice Hall: Long Grove, IL, USA, 2001.

34. Rosas, J.; Lopez, O.; Missimer, T.M.; Coulibaly, K.M.; Dehwah, A.H.; Sesler, K.; Lujan, L.R.; Mantilla, D. Determination of hydraulic conductivity from grain-size distribution for different depositional environments. Groundwater 2014, 52, 399-413. [CrossRef]

35. Sahu, S.; Saha, D. Empirical Methods and Estimation of Hydraulic Conductivity of Fluvial Aquifers. Environ. Eng. Geosci. 2016, 22, 319-340. [CrossRef]

36. Hazen, A. Physical Properties of Sands and Gravels with Reference to Use in Filtration; Report to Massachusetts State Board of Health; Massachusetts State Board of Health: Boston, MA, USA, 1892.

37. Kozeny, J. Uber kapillare leitung der wasser in boden. R. Acad. Sci. Vienna Proc. Cl. I 1927, 136, 271-306.

38. Carman, P.C. Flow of Gases through Porous Media; Academic Press: Cambridge, MA, USA, 1956.

39. Hillel, D. Introduction to Environmental Soil Physics; Academic Press: Cambridge, MA, USA, 2003.

40. Kilpatrick, F.A.; Cobb, E.D. Measurement of Discharge Using Tracers; Technical Report; Department of the Interior, US Geological Survey: Washington, DC, USA,1985.

41. Rosenberry, D.O.; LaBaugh, J.W. Field Techniques for Estimating Water Fluxes between Surface Water and Ground Water; Technical Report; Geological Survey (US): Washington, DC, USA, 2008.

42. Runkel, R.L. On the use of rhodamine WT for the characterization of stream hydrodynamics and transient storage. Water Resour. Res. 2015, 51, 6125-6142. [CrossRef]

43. Cooper, H.H.; Jacob, C.E. A generalized graphical method for evaluating formation constants and summarizing well-field history. Eos Trans. Am. Geophys. Union 1946, 27, 526-534. [CrossRef]

44. Hantush, M.S.; Jacob, C.E. Non-steady radial flow in an infinite leaky aquifer. Eos Trans. Am. Geophys. Union 1955, 36, 95-100. [CrossRef]

45. Everts, C.; Kanwar, R. Evaluation of rhodamine WT as an adsorbed tracer in an agricultural soil. J. Hydrol. 1994, 153, 53-70. [CrossRef]

46. Bencala, K.E.; Rathbun, R.E.; Jackman, A.P.; Kennedy, V.C.; Zellweger, G.W.; Avanzino, R.J. Rhodamine WT dye losses in a mountain stream environment. J. Am. Water Resour. Assoc. 1983, 19, 943-950. [CrossRef]

47. Jones, D.R.; Jung, R.F. Analytical problems arising from the use of bromide and rhodamine WT as co-tracers in streams. Water Res. 1990, 24, 125-128. [CrossRef]

48. Mukherjee, A.; Fryar, A.E.; LaSage, D.M. Using tracer tests to assess natural attenuation of contaminants along a channelized Coastal Plain stream. Environ. Eng. Geosci. 2005, 11, 371-382. [CrossRef]

49. Bredehoeft, J.D. Response of well-aquifer systems to earth tides. J. Geophys. Res. 1967, 72, 3075-3087. [CrossRef]

50. Hsieh, P.A.; Bredehoeft, J.D.; Rojstaczer, S.A. Response of well aquifer systems to Earth tides: Problem revisited. Water Resour. Res. 1988, 24, 468-472. [CrossRef]

51. Rojstaczer, S.; Riley, F.S. Response of the water level in a well to earth tides and atmospheric loading under unconfined conditions. Water Resour. Res. 1990, 26, 1803-1817. [CrossRef]

52. MacAllister, D.; Jackson, M.; Butler, A.; Vinogradov, J. Tidal influence on self-potential measurements. J. Geophys. Res. Solid Earth 2016, 121, 8432-8452. [CrossRef] 